\title{
Nyere forskning om almenprevensjonen - status og kommentar
}

\author{
Av professor, dr. jur. JOHS. ANDEN/ES, Oslo
}

\section{Den nyvakte interesse for almenprevensjonen.}

Så sent som i 1965 kunne det med rette klages over at almenprevensjonen, som har spilt og fremdeles spiller en sentral rolle i strafferettsfilosofi, straffelovgivning og domstolspraksis, har vært nesten totalt fors $\phi \mathrm{mt}$ i kriminologi og sosiologi. Det fantes praktisk talt ingen empirisk forskning om problemet. ${ }^{1}$ ) Senere er imidlertid situasjonen dramatisk forandret. Fra midten av 1960-årene er det kommet en str $\phi \mathrm{m}$ av unders $\phi$ kelser, især i USA, og strømmen viser ikke noe tegn til å avta. Det er kommet flere b $\not \mathrm{ker}$ om almenprevensjonen, ${ }^{2}$ ) og andre er på trappene. I Sverige, hvor almenprevensjon for ikke så lenge siden var et stygt ord, har Brottsförebyggande rådet gitt forskning om almenprevensjon f $\phi$ rste prioritet. Sommeren 1975 holdt rådet et internasjonalt seminar om emnet, og det resulterte $\mathrm{i}$ en publikasjon på nær 400 sider med foredrag og diskusjonsref erater. ${ }^{3}$ )

I den største del av dette århundre har en behandlingsorientert ideologi dominert blant progressive og humant innstilte mennesker $\mathrm{i}$ den vestlige verden, og kriminologer flest har hørt hjemme i denne leir. Idéer om straff og avskrekking er blitt sett på som noe avlegs, primitivt og brutalt. Slagordet at straff ikke hindrer forbrytelser, er derfor blitt akseptert som vitenskapelig sannhet på et helt utilstrekkelig grunnlag.

Det har åpenbart innenfor samfunnsvitenskapen vært psykologiske hemninger mot å beskjeftige seg for alvor med almenprevensjonen. Sosiologen Jack P. Gibbs, en av pionerene på dette område, sa i et seminar i 1972: „Dommere, politifolk, og til og

1) Se min generalrapport til den internasjonale kriminologikongress i Montreal i 1965, trykt i norsk versjon under tittelen „Straff og almenprevensjon" i Tidsskrift for Rettsvitenskap 1966 s. 1-47 (nå også i min artikkelsamling „Straff og lovlydighet", 2. utg. Oslo 1975).

2) F. E. Zimring, Perspectives on Deterrence, National Institute of of Mental Health (1971); F. E. Zimring \& G. J. Hawkins, Deterrence The Legal Threat in Crime Control (1973); Jack P. Gibbs, Crime, Punishment, and Deterrence (1975). Jeg nevner også min egen bok „Punishment and Deterrence“ (1974) (i det vesentlige en engelsk ver"jon av ,Straff og lovlydighet“) og Günther Kaiser, Verkehrsdelinquenz und Generalprävention (1970).

3) General Deterrence - A Conference on Current Research and Standpoints. Utgitt av Brottsförebyggande rådet (1975). I det følgende sitert som konferansereferat General Deterrence. 
med advokater har gitt uttrykk for forbauselse over min forskning om almenprevensjonen; de ser åpenbart på det som en un $\phi \mathrm{d}$ vendig demonstrasjon av det pinlig åpenbare. Men noen av mine samfunnsvitenskapelige kolleger ser ut til å betrakte min forskning som et fors $\phi k$ på å gjenopplive en ille ansett og reaksjonær idé." *)

I løpet av de to siste tiår er behandlingsideologien brutt sammen. Det er blitt klart at nåtidens behandlingsvitenskap ikke kan gi oss noen oppskrift for behandling av lovovertredere. Forskningsmaterialet peker utvetydig i retning av at det spiller liten rolle for tilbakefallsrisikoen hvilken reaksjon vi velger. Heller ikke vet vi noe om når en fengslet lovovertreder $b \phi r$ l $\phi$ slates for at sjansene for et fremtidig lovlydig liv skal være størst mulig. Samtidig har vi fått et klarere blikk for den rettsusikkerhet og urettferdighet som kan bli resultatet hvis vi fors $\varnothing$ ker å sette behandlingsidéen ut i livet. Erkjennelsen av at et reaksjonssystem overfor lovbrudd ikke kan bygge på behandlingstanken, har gjort at studiet av andre formål for strafferettssystemet er kommet mer i fokus. For å sette saken på spissen: Mens spørsmålsstillingen tidligere ofte var: almenprevensjon eller individualprevensjon? er den i stigende grad blitt: almenprevensjon eller ingen reaksjon?

Meget av diskusjonen om almenprevensjonen har vært følelsesladet og har ikke skilt klart mellom empiriske spørsmål og verdisp $\phi \mathrm{rsmål}^{5}{ }^{5}$ ) En type spørsmål er om truselen om straff virker, f. eks. om en endring i oppdagelsesrisikoen eller i straffens strenghet vil medføre noen virkning for kriminalitetens omfang, og i tilfelle hvor stor virkning. En annen type spørsmål er om og i hvilken utstrekning det er moralsk forsvarlig eller politisk akseptabelt å gjøre bruk av systemet med straffetrusler og straff. Noen typer av straff vil bli avvist $i$ et sivilisert samfunn uten hensyn til deres mulige effektivitet, fordi de strider mot våre forestillinger om menneskeverdet. Man vil ikke gjeninnf $\varnothing r e$ avhugging av hender, brennemerking i pannen eller utstilling $\mathrm{i}$ offentlig gapestokk, uansett hva man tror om den avskrekkende virkning av slike straffer. Men i den utstrekning mulige almenpreventive virkninger er av betydning for den kriminalpolitiske vurdering, sier det seg selv at disse virkninger bør s $\phi$ kes kartlagt så objektivt som mulig som grunnlag for de kriminalpolitiske avgjørelser. Alt for ofte har tilnærmingen vært den motsatte: De kriminalpolitiske vurderinger har vært det primære og synet på empiriske spфrsmål har vært farget av dette utgangspunkt. De

4) Jack P. Gibbs i ,The Economics of Crime and Punishment", utg. av Simon Rottenberg (1973), s. 115.

5) Se nærmere Andenæs, Straff og lovlydighet s. 38-42. 
empiriske unders $\phi$ kelser om almenprevensjonen fra de senere år, representerer her noe nytt, selv om de forel $\phi$ pig har f $\phi$ rt til lite av sikre resultater. Både forskningsmetodikken og tolkingen av resultatene er preget av en raskt $\phi$ kende innsikt.

\section{Sosialфkonomenes innmarsj på forskningsfeltet.}

Et interessant trekk ved utviklingen, særlig i USA, er at sosialфkonomene har gjort sitt inntog i diskusjonen og forskningen om almenprevensjonen. ${ }^{6}$ )

På to punkter representerer $\phi$ konomene noe nytt. For det f $\phi$ rste bygger de på et syn på kriminalitet og kriminell motivasjon som står i skarp kontrast til det som er vanlig hos sosiologer og psykiatere. Økonomene starter gjerne fra det utgangspunkt at et lovbrudd er resultatet av et rasjonelt valg. Som $\phi$ konomene Meiselman og Tullock uttrykker det: Økonomer er tilb $\phi$ yelige til a tro at kriminalitet ,in most cases is simply a business oriented economic activity which is undertaken for much the same reasons as other types of economic activity“. Fra dette utgangspunkt trekkes ofte kriminalpolitiske slutninger ved hjelp av generell pristeori. Meiselman og Tullock fortsetter: „To reduce the frequency of crime, economists generally recommend we raise the cost of $\operatorname{crime}^{\text {" }} .^{7}$ )

Nå har jo ikke $\phi$ konomer i kraft av sitt fag noen særlig innsikt i motivasjonsmekanismene hos lovovertredere og potensielle lovovertredere, og det synes noe sterkt $\mathrm{i}$ annen halvpart av det tyvende århundre å gå tilbake til det forenklede syn på menneskelig motivasjon som modellen om det rasjonelle valg representerer. Å bygge en modell på et slikt utgangspunkt kan være rimelig på noen områder, f. eks. med hensyn til mange hvitsnippforbrytelser. På andre områder virker det lite realistisk. Å tale om rasjonelt valg i forbindelse med drap som f $\varnothing$ lge av familiekonflikter eller fylletretter, gir lite mening. Til denne innvending kan det vel svares at modellen kan være fruktbar hvis et tilstrekkelig antall opptrer rasjonelt, selv om langt fra alle gjør det, og at erfaring får vise hvor nyttig modellen kan være.

Det annet bidrag fra $\phi$ konomene ligger i de statistiske metoder som de har utviklet innenfor sitt eget fag. Min manglende inn-

6) Et arbeid som har $\phi$ vet stor innflytelse er Gary S. Becker, Crime and Punishment: An Economic Approach. Journal of Political Economy Vol. 50 (1968) s. 169. En samling av bidrag av фkonomer er ,The Economics of Crime and Punishment", utgitt av Simon Rottenberg (1973). Et nordisk bidrag fra фkonomisk side er Göran Skogh, Analys av allmänpreventionen med utgångspunkt från ekonomisk beslutsteori. Nordisk Tidsskrift for Kriminalvidenskab 1972 s. 293-310.

$\left.{ }^{7}\right)$ Begge sitater er fra forordet til ,The Economics of Crime and Punishment". 
sikt i statistiske metoder avskjærer meg fra noen selvstendig vurdering på detite punkt, men det later til at $\phi$ konometrisk teori har utviklet mer utsagnskraftige statistiske metoder enn de fleste sosiologer har til sin disposisjon. En annen sak er at den mest raffinerte metodikk ikke kan oppveie svakheter i grunnlagsmaterialet. $\mathrm{Og}$ manglende generelt kjennskap til kriminologi og strafferett kan nok ha ført til at de $\phi$ konomiske statistikere undertiden har undervurdert svakhetene ved materialet.

Dessverre ser det ikke ut til å ha vært så megen kontakt mellom $\phi$ konomer og sosiologer som man kunne ha $\phi$ nsket. Sosiologene har for det meste begrenset seg til diskusjon og kritikk av andre sosiologers bidrag, og tilsvarende har $\phi$ konomene begrenset sin diskusjon til bidrag fra andre $\phi$ konomer. Det er så å si to str $\phi$ mmer av forskning som l $\phi$ per ved siden av hverandre uten å flyte sammen. Hverken sosiologene eller $\phi$ konomene synes for $\phi$ vrig å ha noe kjennskap til den diskusjon som har funnet sted blant strafferettsjurister.

\section{Almenprevensjon og avskrekking.}

I det følgende skal jeg gi en oversikt over de senesle års forskning, særlig i USA. Den kan inndeles i fire kategorier:

(1) Sammenlikning mellom geografiske områder,

(2) Sammenlikninger over tid (,f $\varnothing \mathbf{r}-o g$-etter“ forskning),

(3) Intervjuunders $\phi$ kelser om kunnskap og innstillinger,

(4) Eksperimentelle studier.

Noen av forskerne har kombinert flere metoder.

Ved studiet av engelskspråklig litteratur er det et terminologisk sp $\phi$ rsmål man må være oppmerksom på. I nordisk litteratur er utirykket almenprevensjon (generalprevensjon) innarbeidet som betegnelse for de motiverende virkninger som utgår fra straffetruselen og strafferettsapparatet. Uttrykket omfatter både den avskrekkende og den moralske eller sosialpedagogiske virkning. ${ }^{8}$ ) I nyere nordisk litteratur har Alf Ross og Klaus Mäkelä hevdet at straffesystemets almenpreventive virkning i f $\phi$ rste rekke beror på dets evne til å styrke og forme befolkningens moralske misbilligelse overfor de forbudte handlinger. ${ }^{9}$ ) I den finske Straffrättskommitténs principbetänkande av mars 1977 er det lagt stor vekt på ,,det element av auktoritativt samhälleligt klander som straffet ger uttryck för".

8) Den moralske komponent av almenprevensjonen har jeg behandlet nærmere i "Strafferett og moraldanning“, Festskrift til Per Olof Ekelöf (1972) s. 38-66 (nå også i samlingen Straff og lovlydighet).

9) Alf Ross, Kampen mod straffen. NTfK 1969 s. 2 (se s. 19, 28-29); Klaus Mäkelä, Om straffens verkningar. Oikeustiede VI (1975) s. 237280 (se s. 253,268 ). 
På engelsk taler man gjerne om deterrence. Det betyr avskrekkelse, motivasjon gjennom frykt. Enkelte forfattere tar imidlertid uttrykket $\mathrm{i}$ en videre betydning, slik at det også omfatter den moralske komponent. ${ }^{10}$ ) Andre tar det i den snevrere betydning i overensstemmelse med vanlig språkbruk. ${ }^{11}$ ) Svært mange nevner ikke definisjonsproblemet i det hele tatt, og det er ikke så godt å vite hvad de mener.

Det er mulig at det skyldes ordets makt over tanken at de moralske virkninger av straffesystemet er blitt fors $\phi \mathrm{mt}$ i den amerikanske forskning om almenprevensjonen. Det er åpenbart vanskelig $\mathrm{i}$ forskning å skille mellom de to aspekter av almenprevensjonen. Men hvis man bare har fryktmotivet for $\phi y e$, blir perspektivet for snevert. Jeg nevner to momenter:

(1) Når man trekker de moralske virkninger inn, blir det n $\phi d$ vendig å anvende et langtidsperspektiv. Som den engelske kriminolog Nigel Walker har sagt: „Den ene generasjons lovgivning kan bli neste generasjons moral" ${ }^{12}$ ) Hvis man tror at en vesentlig del av lovens virkning ligger i dens evne til å opprettholde og styrke sosiale normer, kan man ikke vente plutselige endringer $i$ kriminalitet som et resultat av endringer i lovgivning eller rettshåndhevelse. Betydningen av langtidsperspektivet kan kanskje belyses ved to unders $\phi$ kelser av innstillingene til promillekj $\phi$ ring. Intervjuunders $\phi$ kelser i England $f \phi r$ og etter innf $\phi$ ringen av en fast promillegrense i 1967 viste at den nye lov og all publisitet omkring den ikke hadde hatt noen påtakelig betydning for synet på alkohol og motorvognkjøring. ${ }^{13}$ ) En norsk Gallupunders $\varnothing$ kelse fra 1976 viste derimot et meget høyt samsvar mellom lovens vurderinger og innstillinger hos publikum. Et overveldende flertall mente således at kjøreferdigheten ble nedsatt ved en alkoholpåvirkning på over 0,5, og at dette var den riktige grense for straffbarhet. ${ }^{14}$ ) Nettopp denne konsentrasjon omkring lovens grense, som har stått uendret siden 1936, er et sterkt indisium på at det her har lykkes lovgivningen å nå frem med sitt budskap.

10) Således Zimring \& Hawkins, Deterrence - The Legal Threat in Crime Control (1973), s. 77.

11) Således Gibbs i The Economics of Crime and Punishment (1973) s. 115 og i boken Crime, Punishment, and Deterrence (1975), se s. 2 o. fl. st.

12) Nigel Walker, Morality and the Criminal Law. The Howard Journal, Vol. 11 (1964) s. 209.

13) Sheppard, The 1967 Drink and Driving Campaign: A Survey Among Drivers. Road Research Laboratory Report LR 230 (1968).

14) Se nærmere Ragnar Hauge, Drinking - and - Driving in Norway: Biochemistry, Law and Mortality. Scandinavian Studies in Crimonology Vol. 6 (under trykning). 
(2) Forskning om almenprevensjonen har vesentlig vært opptatt av virkningene av strengheten av straffen og risikoen for oppdagelse og dom. Med tanke på de moralske virkninger kan en tredje variabel være vel så viktig, nemlig oppfatningen i befolkningen av lovens og strafferettssystemets legitimitet. For å oppnå en moralsk virkning må loven og strafferettssystemet oppleves som en ut $\varnothing$ velse av legitim autoritet. En følelse av manglende legitimitet kan forekomme på flere nivåer. Det kan dreie seg om en total avvisning av det nåværende samfunn, som oppfattes som urettferdig og undertrykkende. Det kan være rettsapparatet som blir opplattet som vilkårlig og diskriminerende. Eller det kan være den spesielle straffebestemmelse som oppfattes som et illegitimt inngrep; man kan tenke på amerikanske studenters innstillinger til marihuanalovene, på arbeideres innstilling til lovgivning som griper inn i streikeretten, eller på feministgruppers innstillinger til restriktiv abortlovgivning. Å håndheve forbud som av store grupper i befolkningen blir betraktet som utidige inngrep, kan fremprovosere bitterhet, aggresjon og endog vold i stedet for lovlydighet. „Lovens prestisje“, for å bruke et uttrykk av den polske rettssosiolog Adam Podgorecki, ${ }^{15}$ ) kan variere fra det ene land til det andre, og fra den ene tidsperiode til den andre. Meget taler for at den er lav i våre dagers USA, iallfall i storbyene. Én grunn ligger i rasemotsetningene og f $\varnothing$ lelsen hos den sorte befolkning av å være diskriminert. I en atmosfære av uvilje og aggresjon overfor samfunnet og rettsapparatet kan endog en lovlig og velbegrunnet arrestasjon bli gnisten som utl $\phi$ ser en katastrofe av vold og $\phi$ deleggelser. Det var således tilfellet ved raseoppt $\phi$ yene i Watts i $1965 .^{16}$ ) En annen grunn ligger i en utbredt mistillit til hederligheten hos det politiske lederskap, politiet og rettsapparatet. Presidentens Crime Commission pekte på dette i sin drøftelse av organisert kriminalitet. ${ }^{17}$ ) En teori som ikke tar slike faktorer i betraktning, mangler noe vesentlig.

Ved siden av den avskrekkende og den moralske virkning av straffetruselen, bruker man også å nevne den vanedannende. ${ }^{18}$ ) Det er klart at vanedanning spiller en betydelig rolle i oppdragelsen til lovlydighet; et praktisk viktig eksempel er motorvogn-

15) Adam Podgorecki, The Prestige of the Law, Acta Sociologica Vol. 10 (1966) s. 81.

16) Beskrevet i Task Force Report: Crime and Its Impact - An Assessment. The President's Commission on Law Enforcement and Administration of Justice (1967) s. 119-120.

${ }^{17}$ ) Task Force Report: Organized Crime. The President's Commission on Law Enforcement and Administration of Justice (1967) s. 24.

18) Se nærmere Andenæs, Straff og lovlydighet s. 12, 139-141. 
f $\varnothing$ reres reaksjon på trafikksignaler. Men vanedanning er et sekundært fenomen. En vane oppstår ved gjentagelse av en adferd, som opprinnelig er fulgt av andre grunner. En vanemessig lovlydighet forutsetter derfor at loven f $\phi$ rst er fulgt av andre grunner, som kan være avskrekking eller moralpåvirkning fra loven, men ikke beh $\phi$ ver være det.

\section{Diskusjonen om dødsstraffen.}

Dødsstraffen var det f $\varnothing$ rste, og inntil nylig det eneste område hvor det er utf $\phi$ rt forskning for empirisk à klarlegge straffens almenpreventive virkning. Forskningen i USA på dette område går tilbake til omtrent 1920. Det meste av den har vært basert på to metoder: En sammenligning av antallet drap i stater med og uten d $\phi$ dsstraff, og sammenligning av antall drap over tid i stater som har opphevet d $\varnothing$ dsstraffen, og kanskje gjeninnf $\phi$ rt den. Tross metodologiske innvendinger som kan gjøres mot meget av denne forskning, har den overbevist de fleste kriminologer om at d $\phi \mathrm{ds}$ straff for drap i stedet for livsvarig fengsel ikke har noen påviselig virkning for antallet drap. Det vil si at hvis der er en slik virkning, en mulighet som er vanskelig å motbevise, er den ikke av en slik størrelse at den lar seg påvise statistisk blandt alle de andre faktorer som påvirker tallene for drap. Unders $\varnothing$ kelser i andre deler av verden har ledet til samme konklusjon. ${ }^{19}$ )

Det er en svakhet ved den forskning som her er omtalt, at den stort sett bare har festet seg ved den rettslige adgang til å anvende d $\varnothing$ dsstraff. Det er tenkelig at det kan spille en st $\phi$ rre rolle hvor ofte dødsstraffen blir brukt enn om den eksisterer på papiret. Bare Schuessler og Bailey har fors $\phi \mathrm{kt}$ å sammenholde tallene for drap med hyppigheten av eksekusjoner i stater med d $\varnothing$ dsstraff. ${ }^{20}$ ) De fant begge en svak, men (med ett unntak) ikke statistisk relevant negativ sammenheng mellom antallet eksekusjoner og antallet drap. Spфrsmålet om en mer utstrakt bruk av dødsstraffen kunne ha hatt betydning, står for så vidt åpent.

Unders $\phi$ kelsene om d $\varnothing$ dsstraffens virkninger har vært meget viktige som argumenter for avskaffelse av d $\varnothing$ dsstraff. Undertiden. er de også brukt som utgangspunkt for generelle utsagn om virkningsl $\phi$ sheten av straffetrusler. Slike generaliseringer er åpenbart uberettigede. For det f $\varnothing$ rste angår unders $\phi$ kelsene ikke d $\varnothing \mathrm{ds}$ straffens almenpreventive virkning i seg selv, men forskjellen i

19) For det britiske samvelde kan vises til Nigel Walker, Crime and Punishment in Britain, Second revised edition 1968, s. 237-241.

${ }^{20}$ ) Karl F. Schuessler, The Deterrent Influence of the Death Penalty. Annals of the American Academy of Political and Social Science Vol. 284 (1952) s. 54; William C. Bailey, Murder and the Death Penalty. Journal of Criminal Law \& Criminology Vol. 65 (1974) s. 416. 
virkning mellom truselen om d $\varnothing$ dsstraff og truselen om livsvarig fengsel, som vil være det normale alternativ der hvor d $\phi$ dsstraff i det hele kan komme på tale. Når alternativet er så drastisk, er det psykologisk forståelig om forskjellen har liten motiverende virkning, endog i tilfelle av koldblodig, overlagt drap. Morderen setter hele sin fremtid på spill under enhver omstendighet. Han satser på ikke å bli oppdaget; blir han oppdaget, er spillet tapt. Videre er drap en meget spesiell forbrytelseskategori, omgitt av sterke moralske og sosiale tabuforestillinger. Gjerningsmannen handler ofte under opphisselse, eller handlingen er veien ut av personlige konflikter som han ikke mestrer. Det er derfor rimelig å tenke seg at forskjell i straffenivå har mindre betydning her enn ved de fleste andre kriminalitetstyper. Det kan også nevnes at d $\varnothing$ dsstraff for drap innebærer en viss indre motsigelse som

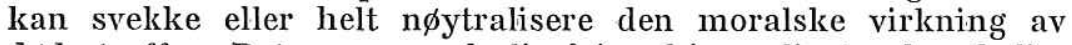
d $\phi$ dsstraffen. Det er noe underlig å innskjerpe livets ukrenkelighet ved å ta livet av drapsmannen.

Av disse og andre grunner har resultatene fra d $\varnothing$ dsstraffunders $\phi$ kelsene lite å gi utenfor akkurat det felt som unders $\varnothing$ kelsene gjelder, nemlig d $\varnothing$ dsstraff for drap under nåtidens forhold. Det er mange historiske vitnesbyrd om at d $\varnothing$ dsstraff under krig, revolusjon og lignende forhold kan ha meget større virkning enn noen annen straff. ${ }^{21}$ ) Årsaken er antakelig forst og fremst at d $\varnothing$ dsstraffen er definitiv, mens en trusel om livsvarig fengsel under de usikre forhold ikke oppfattes som en realitet på samme måte som ellers. At unders $\varnothing$ kelsene om d $\varnothing$ dsstraffen ikke kan fortelle noe om den relative effekt av bot, fengsel eller betinget dom for tyveri, promillekjøring eller skattesnyteri, er innlysende. ${ }^{22}$ )

Forskningen om d $\phi$ dsstraffens virkninger tok en ny vending med Chicago- $\phi$ konomen Ehrlich's studie. Ehrlich var tidligere kjent som en av de mest fremtredende $\phi$ konomer som hadde gitt seg inn på spфrsmålet om almenprevensjon. ${ }^{23}$ ) I sitt arbeid om d $\varnothing$ dsstraffen tok han for seg opplysningene om henrettelser og statistikken for drap i de forskjellige amerikanske enkeltstater i perioden 1933-1969, og bearbeidet materialet med statistisk regresjonsteknikk for å se om der var noen sammenheng. Og resultatene var oppsiktsvekkende: Han konkluderte med at materialet

21) Se Andenæs, Straff og lovlydighet s. 27-28, 55-56; Paul E. Meehl, Law and the Fireside Inductions: Some Reflections of a Clinical Psychologist. Journal of Social Issues, Vol. 27 (1971) s. 73-74 (basert på C. Barnett, The Swordbearers: Supreme Command in the First World War, 1965).

${ }^{22}$ ) Om n $\varnothing$ dvendigheten av å sondre mellom forskjellige typer av lovbrudd se nærmere Straff og lovlydighet s. 14-24, 76-94.

23) Se nedenfor ved note 38 . 
tydet på at hver henrettelse $\mathrm{i}$ denne periode hadde spart $7-8$ liv. ${ }^{24}$ )

Disse resultater vakte kolossal oppsikt, og de ble også brukt som argument i de saker som verserte for Hфyesterett om d $\phi$ dsstraffens forenlighet med forfatningens forbud mot ,grusomme og usedvanlige straffer". Som ventelig var, ble Ehrlich's materiale og metoder omhyggelig gått etter i s $\varnothing$ mmene. Bowers og Pierce har i en artikkel i Yale Law Journal kommet med en meget skarp kritikk. ${ }^{25}$ ) Kritikken kan sammenfattes i to punkter. For det første at de statistiske data som Ehrlich har bygget på, er for upålitelige til å gi grunnlag for bestemte slutninger. For det annet at Ehrlich's resultater skyldes hans valg av tidsperiode. Hvis man bruker hans egen metode, men ikke regner med de siste 5 år av perioden, da dødsstraffen så å si var gått av bruk i praksis, gir tallene ikke lenger noen st $\varnothing$ tte for at bruken av d $\phi$ dsstraff skulle være av betydning for antallet drap. De statistiske beregningsmetoder som såvel Ehrlich som hans kritikere bruker, unndrar seg min bed $\phi$ mmelse, men den fremf $\phi$ rte kritikk kan forståes uten kjennskap til statistisk raffinement, og virker på meg overbevisende. - Det kan nevnes at den federale h $\phi$ yesterett $\mathrm{i}$ sine dommer fra 1976 om d $\varnothing$ dsstraffens grunnlovmessighet ga uttrykk for at spфrsmålet om d $\phi$ dsstraffens effektivitet hadde vært diskutert lenge, uten at diskusjonen hadde f $\varnothing$ rt til noe klart resultat.

\section{$V$. Komparative undersøkelser av geografiske områder.}

Den mest brukte forskningsmetodikk i USA siden slutten av 1960-årene har vært å sammenligne geografiske enheter, som oftest de enkelte stater innen unionen, og fors $\phi$ ke å finne sammenheng mellom kriminalitetshyppigheten på den ene side, og vissheten og strengheten av straffen på den annen side. I klassisk avskrekkingsteori ble hurtighet nevnt ved siden av visshet og strenghet, men jeg kjenner ikke noen studie som tar sikte på å finne sammenheng mellom kriminalitetshyppighet og hurtigheten

24) Isaac Ehrlich, The Deterrent Effect of Capital Punishment: A Question of Life and Death. American Economic Review Vol. 65 (1975) s. 397. Hans resultater var presentert et par år tidligere i et "Working Paper", som ikke er offentliggjort, men som har vært kjent av mange og ble omtalt av Gordon Tullock i en artikkel i The Public Interest 1974 .

$\left.{ }^{25}\right)$ William J. Bowers og Glenn L. Pierce, The Illusion of Deterrence in Isaac Ehrlich's Research on Capital Punishment. The Yale Law Journal Vol. 85 (1975) s. 187. En mer utførlig version av kritikken har de gitt i et upublisert manuskript „,Deterrence, Brutalization or Nonsense", Center for Applied Social Research, Northeastern University, Boston. Et tilsvar fra Ehrlich i Yale Law Journal Vol. 85 (1976) s. 359 har ikke vært tilgjengelig for meg under arbeidet med denne artikkel. 
av rettsforf $\phi$ lgningen. En slik unders $\phi$ kelse ville være teknisk vanskelig å foreta, og ut fra common sense er det naturlig å tenke seg at hurtighet har mindre betydning enn at straffen rammer sikkert og strengt. Hvis man har sikkerhet for at den skyldige ikke unngår sin straff og ikke slipper for lett, har det antakelig mindre betydning om rettens kvern maler fort eller langsomt.

Blandt sosiologene var det Gibbs og Tittle som uavhengig av hverandre var pionerene i slutten av 1960-årene. ${ }^{26}$ ) Gibbs sammenlignet hyppigheten av drap i de forskjellige stater med visshet (certainty) og strenghet (severity) av straffen. Som mål for vissheten brukte han forholdet mellom personer inntatt i fengsel for drap og antallet drap kjent av politiet. Som mål for strengheten brukte han det gjennomsnittlige antall måneder sont av fanger som satt inne for drap på en bestemt dag. Ved bruk av statistisk analyse etter kji-kvadrat metoden fant han at det var en negativ sammenheng mellom visshet og strenghet av straffen og hyppigheten av drap, men at sammenhengen var meget sterkere for vissheten enn for strengheten. Gibbs var klar over svakhetene ved materialet og problemene ved tolkingen. Han betraktet derfor ikke sine funn som avgjørende, men mente at de satte spфrsmålstegn ved den alminnelige påstand at det ikke er noen sammenheng mellom de strafferettslige reaksjoner og kriminalitetshyppigheten.

Tittle brukte en lignende metodikk, men utvidet området for unders $\phi$ kelsen til alle de syv kriminalitetstyper som er omfattet av de federale „Uniform Crime Reports“ (de såkalte Index crimes: drap, legemskrenkelse, seksualforbrytelser, ran, innbrudd, tyveri og biltyveri). Han brukte også andre statistiske metoder i sine beregninger, og han fors $\phi$ kte å kontrollere for sosiale faktorer som er av betydning for kriminaliteten, slik som urbaniseringsgrad, utdanningsnivå, alderssammensetning av befolkningen osv. Tittle fant negativ sammenheng mellom vissheten for fengsel og kriminalitetshyppigheten for alle forbrytelsestyper, men størrelsen av sammenhengen varierte fra nesten 0 $(0,08)$ for biltyveri til en sterk sammenheng ved seksualforbrytelser $(0,57)$. Når det gjaldt strengheten fant han ingen sammenheng, bortsett fra drap. Og med dette unntak konstaterer han at ,det ser ut til at strengheten i seg selv rett og slett er irrelevant i kontrollen av avvikende adferd". Dette er selvsagt en uholdbar generalisering fra unders $\varnothing$ kelsen. Det meste et negativt resultat kunne si, er at forskjeller i strenghet av den storrelse som man

26) Jack P. Gibbs, Crime, Punishment, and Deterrence. Social Science Quarterly Vol. 48 (1968) s. 515; Charles L. Tittle, Crime Rates and Legal Sanctions. Social Problems Vol. 16 (1969) s. 409. 
finner mellom enkeltstatene i USA, ikke gir noe påviselig utslag for tradisjonelle forbrytelser.

Disse studier av Gibbs og Tittle ga st $\varnothing$ tet til en hel rekke nye unders $\phi$ kelser som ikke skal gjennomgås her. ${ }^{27}$ ) Stort sott har de gått i retning av å bekrefte at det er en sammenheng mellom vissheten av straffen og kriminalitetshyppigheten, mens det er vanskeligere å påvise et sikkent mønster når det gjelder strenghet. Enkelte forskere har pekt på at det ser ut til å være en negativ sammenheng mellom visshet og strenghet av straffen, og at dette kan virke $\mathrm{i}$ retning av å skjule den betydning som strengheten i seg selv kan ha. Med andre ord: Jo strengere straffene er, jo vanskeligere ser det ut til å være å få de skyldige $d \phi \mathrm{mt}$. For d $\phi$ dsstraffens vedkommende er en slik megativ sammenheng bekreftet både av historisk erfaring og common sense, og når det gjelder straff for overtredelser av fartsgrenser, viste unders $\varnothing$ kelsen om den vel kjente „Connecticut crackdown“ en lignende sammenheng. ${ }^{28}$ )

Det kan være grunn til å peke på at når disse unders $\phi$ kelser taler om ,visshet“ og ,strenghel“" av straffen, har disse uttrykk ikke samme betydning som de pleier ha i den teoretiske diskusjon om almenprevensjonen. Vanligvis tenker man med det f $\phi r-$ ste på risikoen for å bli straffet, uansett hva straffen blir (fengsel, bot, betinget dom etc.). Gibbs og de som har fulgt i hans fotspor, har konsentrert seg nesten utelukkende om risikoen for fengsel (målt ved forholdet mellom personer innsatt i fengsel og lovoventredelser meldt til politiet). Og fengsel betyr her statsfengsel; lokalfengslene (jails), og dermed korttidsstraffene, or holdt utenfor. For en forbrytelse som drap har denne begrensning liten betydning, siden straffen her nesten alltid vil være langvarig fengsel. For lovovertredelser som innbrudd, tyveri og motorvogntyveri vil forskjellen derimot være meget stor, siden andre reaksjoner enn fengsel er det vanlige. Forskjell mellom stater med hensyn til risikoen for å få fengselsstraff, kan derfor ha like meget eller mer å gjøre med forskjell i straffutmåling enn med forskjell i risikoen for oppdagelse og domfellelse. (Selve uttrykket „visshet“" kan for $\emptyset$ vrig sies å være noe misvisende når det for mange typer av forbrytelser bare er tale om en risiko på noen få prosent eller enda mindre).

${ }^{27}$ ) En mer detaljert redegjørelse for unders $\varnothing$ kelser publisert innen utgangen av 1974 er gitt i min artikkel ,General Prevention Revisited: Research and Policy Implications". Journal of Criminal Law and Criminology Vol. 66 (1975) s. 338.

${ }^{28)}$ Se Donald T. Campbell og H. Laurence Ross, The Connecticut Crackdown on Speeding: Time Series Data in Quasi-Experimental Analysis. Law and Society Review Vol. 3 (1968) s. 33. 
Tilsvarende er definisjonen av strenghet $\mathrm{i}$ de omtalte unders $\varnothing$ kelser, som utelukkende konsentrerer seg om lengden av fengselsstraffene, ikke den samme som i den teoretiske diskusjon om almenprevensjonen. En sammenligning mellom lengden av de fengselsstraffer som blir sont i de forskjellige stater, gir ikke noe totalbilde av strengheten i straffutmålingen. I én stat kan der være en utstrakt bruk av bot og betinget dom, og lange straffer i de få tilfelle hvor fengsel blir brukt. I en annen stat kan det være større bruk av korte fengselsstraffer. Den første vil da i unders $\phi$ kelsene fremtre som den strengeste, noe som kan være helt misvisende ut fra en totalvurdering av straffutmålingen. Det kan tilf $\varnothing$ yes at den utstrakte bruk av tidsubestemt straff, som overlater til egne utvalg (parole boards) å bestemme hvor mye av fengselsstraffen som skal sones, medf $\phi$ rer at det er liten offentlighet omkring dette spфrsmål i USA, og derfor sannsynligvis lavt samsvar mellom den virkelige strenghet og publikums oppfatninger om strengheten.

Av disse grunner vil det ikke være riktig å tolke resultatene slik at vissheten om straff har en almenpreventiv effekt, mens det er tvilsomt om strengheten av straffen har. Det som resultatene tyder på — med de reservasjoner som vil fremgå av det følgende - or at bruken av fengsel har botydning for kriminalitetshyppigheten, og at forskjell $i$ lengden av fengselsstraffene ikke ser ut til å ha noen særlig betydning, iallfall når straffene ligger på det nivå som er vanlig i USA. Det ville være uholdbart å trekke den slutning at også valget mellom f. eks. bot, fengsel eller betinget dom, eller mellom små og store $b \phi t e r$, er uten noen særlig betydning. Dette ville være en feilslutning av samme art som å generalisere fra forskningen om dødsstraff for drap til andre straffer og andre lovoventredelser.

Det er flere andre forhold som begrenser bærekraften av de omtalte unders $\phi k$ kelser. Det ene er at det i unders $\phi$ kelsene ikke er gjort noe fors $\varnothing \mathrm{k}$ på å skille mellom den almenpreventive og den uskadeliggj $\phi$ rende virkning av frihetsstraffen. Frihetsstraffen avskjærer, iallfall stort sett, den innsatte fra nye forbrytelser så lenge innesperringen varer. At man tar ut av sirkulasjon et antall lovovertredere som ellers ville ha begått nye forbrytelser, har ikke noe med almenprevensjon å gjøre. Hvis man bygger på sammenheng mellom bruken av frihetsstraff og kriminalitetsnivået, kan man derfor komme til å tilskrive almenprevensjonen en virkning som i realiteten skyldes uskadeliggjøring. Ehrlich ${ }^{20}$ )

29) Isaac Ehrlich, Participation in Illegitimate Activities: A Theoretical and Empirical Investigation. Journal of Political Economy Vol. 81 (1973) s. 521 (se s. 535-537 og s. 553). 
og Greenberg ${ }^{30}$ ) har gjort fors $\phi k$ på å anslå virkningen av uskadeliggjørelsen. De er begge kommet til at denne virkning or nokså liten. Er dette riktig for USA, skulle en tro at det i enda høyere grad må gjelde for de nordiske land med deres korte frihetsstraffer. Spфrsmålet beror på i hvilken utstrekning de som sitter inne, er personer med sterk kriminell aktivitet (f. eks. profesjonelle vinningsforbrytere) eller for $\phi$ vere av enkeltstående grove forbrytelser (f. eks. drap)..$^{31}$ )

Enkelte komparative unders $\phi$ kelser bruker andre kriterier enn fengselsstraff som mål for risikoen for sanksjon. Unders $\phi k e l s e r$ av Logan og av Tittle og Rowe har således tatt utgangspunkt i andelen av forbrytelser ,,oppklart ved arrest"; mens Logan sammenliknet enkeltstater, sammenliknet Tittle og Rowe distrikter i staten Florida. ${ }^{32}$ ) Stort sett går resultatene i retning av en negativ korrelasjon mellom sanksjonsrisikoen uttrykt på denne måte og kriminalitetstallene.

Det alvorligste sp $\phi$ rsmålstegn som kan settes ved denne komparative forskning, er om man kan stole på at korrelasjonene mellom sanksjoner og kriminalitetstall gir uttrykk for årsakssammenheng. Sp $\phi$ rsmålet ble reist allerede av Gibbs i hans f $\varnothing$ rste arbeid $\left.^{33}\right)$, og har senere vært drøftet av en rekke forskere uten at man kan si at problemet er blitt l $\phi$ st. Bruken av straff har betydning for kriminalitetens omfang, men omfanget av kriminaliteten har også betydning for bruken av straff. Det er her et vekselvirkningsforhold som er vanskelig å oppklare. Hvis vi tenker oss at en stat av en eller annen grunn har fått en sterk stigning i kriminaliteten, kan dette tenkes å f $\phi$ re til st $\phi$ rre bruk av påtaleunnlatelser, bot og betinget dom for å unngå overbelastning av fengselsvesenet. Men det kan også tenkes å f $\phi$ re til strengere straffer som en motforholdsregel mot kriminalitets $\phi$ kningen. I den første situasjon vil man få en sammenheng mellom mild straffutmålingspraksis og høye kriminalitetstall, som kan feiltolkes i retning av at det er den milde straffutmåling som er ansvarlig for de høye kriminalitetstall. I den annen situasjon vil man få en sammenheng mellom streng straffutmålingspraksis og

30) David F. Greenberg, The Incapacitative Functions of Imprisonment. Some Estimates. Rapport til m $\phi$ te av Society for the Study of Social Problems, Montreal 1974.

31) Jfr. konferanserapport General Deterrence s. 76.

32) Charles H. Logan, Arrest Rates and Deterrence, Social Science Quarterly, December 1975 s. 376. Charles R. Tittle og Alan R. Rowe, Certainty of Arrest and Crime Rates: A Further Test of the Deterrence Hypothesis. Social Forces, Vol. 52 (1974) s. 455. Se også William C. Bailey, Certainty of Arrest and Crime Rates for Major Felonies: A Research Note. Journal of Research in Crime and Delinquency, Vol. 13 (1976) s. 145.

33) Se note 26 foran. 
høye kriminalitetstall, som kan skjule en mulig almenpreventiv virkning av de strenge straffer.

Like viktig er det at det kan foreligge en tredje faktor, som kanskje er vanskelig å identifisere og måle, men som kan påvirke både kriminaliteten og anvendelsen av straff. En slik faktor er det som er blitt betegnet som det normative klima i samfunnet. ${ }^{34}$ ) Hvis den samfunnsmessige ford $\varnothing$ mmelse av visse kriminalitetstyper er sterk, kan dette lede til lave kriminalitetstall og samtidig til strenge straffer, slik at det skapes et inntrykk av at de lave kriminalitetstall skyldes de strenge straffene. Tilsvarende med hensyn til vissheten for sanksjon. En sterk samfunnsmessig ford $\varnothing$ mmelse kan lede til aktiv st $\phi$ tte fra borgerne til politi og retts-

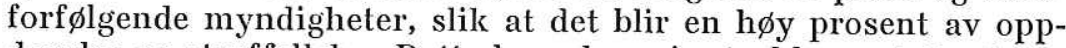
dagelse og straffellelse. Dette kan skape inntrykk av at den høye domfellelsesrisiko er årsak til de lave kriminalitetstall, mens den virkelige årsak kan ligge i det normative klima. Men den strenge samf unnsmessige ford $\phi$ mmelse kan itenkes å ha andre virkninger. Den kan føre til at en stor del av de begåtte forbrytelser blir anmeldt til politiet, slik at de registrerte kriminalitetstall svulmer opp og en mulig almenpreventiv virkning av den strenge og sikre rettshåndhevelse blir skjult.

De forhold som det her er pekt på, kompliserer i h $\phi y$ grad tolkingen av de statistiske sammenhenger. Det er ikke mulig på common sense basis å konstatere med sikkerhet hvilken vei årsakssammenhengen går, og enda mindre å kvantifisere sammenhengene. Så lenge disse sp $\varnothing$ rsmål ikke er $l \varnothing s t$, knytter det seg betydelig usikkerhet med hensyn til konklusjonene.

Etter denne omtale av den sosiologiske forskning skal jeg si noe om den $\phi$ konometriske. Denne litteratur har antatt et betydelig omfang, og jeg har selv bare satt meg inn i noen få av unders $\varnothing$ kelsene.

Silver refererte og vurderte i en oversikt datert februar 1974 19 nyere $\phi$ konometriske studier. ${ }^{35}$ ) Palmer har i en senere oversikt f $\varnothing \mathrm{rt}$ opp 78 arbeider av $\phi$ konomer som teoretisk eller empirisk behandler almenprevensjonen („Deterrence“). ${ }^{36}$ ) Noen av

34) R. G. Salem og W. J. Bowers, Severity of Formal Sanctions as a Deterrent to Deviant Behavior. Law and Society Review Vol. 5 (1970) s. 21; W. J. Bowers og R. G. Salem, Severity of Formal Sanctions as a Repressive Response to Deviant Behavior. Law and Society Review Vol. 6 (1972) s. 427.

$\left.{ }^{35}\right)$ Morris Silver, Punishment, Deterrence, and Police Effectiveness: A Survey and Critical Interpretation of the Recent Econometric Literature (a report prepared for the Crime Deterrence and Offender Career Project, stensilert).

36) Jan Palmer, Economic Analyses of the Deterrent Effect of Punishment: A Review. Journal of Research in Crime and Delinquency Vol. 14 (1977) s. 4. 
dem bruker enkeltstatene som enheter, andre bruker mindre enheter (byer, kommuner, politidistrikter). Alle diskuterer betydningen av vissheten av straff (som regel fengsel), noen diskuterer også virkningen av strengheten av straffen. På grunn av de kompliserte statistiske metoder er det vanskelig for en ikkestatistiker å gjøre seg opp noen begrunnet mening om holdbarheten av resultatene.

Den typiske teknikk for de $\phi$ konometriske unders $\phi$ kelser er å stille opp en kriminalitetsligning (Crime Generation Function) hvor kriminalitetstallene fremtrer som en funksjon av en rekke faktorer, deriblant risikoen for straff. Blant andre faktorer kan f. eks. være tatt med aldersfordelingen i befolkningen, prosenten av ikke-hvite, inntektsulikheter, arbeidsl $\phi$ shet og andre forhold som forskeren anser for viktige, og som det derfor b $\phi \mathbf{r}$ tas hensyn til når man skal beregne virkningen av forskjell i visshet og strenghet av straffen. St $\varnothing$ rrelser fra tilgjengelig statistikk blir innf $\phi$ rt i ligningen, som så blir behandlet ved en eller annen form av regresjonsanalyse. For å kaste lys over de spørsmål om kausalitetens retning som er drøftet ovenfor, brukes gjerne to eller flere ligninger, hvor den avhengig variable i den ene ligning (kriminaliteten) brukes som uavhengig variabel i den annen. ${ }^{37}$ )

Av de $\phi$ konometriske unders $\phi$ kelser skal jeg til illustrasjon nevne Ehrlichs arbeider om betydningen av straffens visshet og strenghet. ${ }^{38}$ ) Han sammenligner enkeltstatene i USA, og bruker lignende mål for visshet og strenghet som Gibbs og Tittle. Han fant at hyppigheten av de enkelte forbrytelseskategorier uten unntak varierer $\mathrm{i}$ omvendt forhold til sannsynligheten av fengselsstraff og den gjennomsnittlige lengde av tid sont i statsfengsler. Han fors $\phi$ kte å skille betydningen av uskadeliggjørelse på grunn av fengselsoppholdet fra den almenpreventive virkning, og konkluderte med at en selvstendig almenpreventiv virkning synes bekreftet. ${ }^{39}$ ) Ehrlich gjorde videre et fors $\varnothing \mathbf{k}$ på å vurdere effektiviteten av rettshåndhevelsen i bekjempelsen av kriminalitet: Er der for meget eller for lite rettshåndhevelse (basert på

37) En elementær fremstilling av de brukte teknikker er gitt av Palmer i den oversiktsartikkel som er nevnt i foregånde note. Det fremgår av Editorial Notes i samme nummer s. 1 at artikkelen er skrevet etter anmodning av redaksjonen til orientering for kriminologer med annen bakgrunn.

38) Isaac Ehrlich, Participation in Illegitimate Activities: A Theoretical and Empirical Investigation. Journal of Political Economy Vol. 81 (1973) s. 521, og samme, The Deterrent Effect of Criminal Law Enforcement. Journal of Legal Studies Vol. 1 (1972) s. 259. Hans unders $\varnothing$ kelse om betydningen av dødsstraff er omtalt foran i avsnitt IV.

39) Ehrlich (1972) s. 267-269, (1973) s. 535-537, 553. Men se kritikken hos Silver s. $19-20$ og 49: Denne bevisf $\varnothing$ rsel er altfor svak til å rettferdiggjøre slutninger om et så sentralt spørsmål. 
1965-tallene) $?^{40}$ ) Hans anslag var at én prosents $\phi \mathrm{kning}$ i utlegg til direkte rettshåndhevelse (law enforcement) ville resultere $\mathrm{i}$ tre prosents nedgang i tallet på forbrytelser. Omsatt i $\varnothing$ konomiske vendinger betyr det at hver million ekstra som man spanderte på rettshåndhevelse, ville redusere det samfunnsmessige tap på grunn av forbrytelser med flere millioner. Men han tilf $\phi y e r$ forsiktigvis at dette resultat ikke kan betraktes som særlig pålitelig.

Morris Silver konkluderte (1974) sin gjennomgang av den $\phi$ konometriske litteratur med f $\phi$ lgende: „Tatt som en helhet demonstrerer resultatene på en overbevisende måte at kriminalitetshyppigheten reduseres ved hфyere sannsynlighet for straff ... Resultatene med hensyn til varigheten av straffene tyder i samme retning som for sannsynligheten for straff, men ikke så overbevisende. St $\varnothing$ rre forsiktighet er påkrevet av mange grunner.“"41) Ved tolkingen av disse utsagn er det viktig å være oppmerksom på at de $\phi$ konometriske unders $\phi$ kelser på samme måte som de sosiologiske, stort sett bare behandler fengsel når de taler om straff (se ovenfor etter note 28). Palmer (1977) nevner en $\varnothing$ konometrisk unders $\phi k e l s e$ fra Canada, som ikke har funnet noen sammenheng mellom fengselsstraffens lengde og kriminalitetshyppigheten ${ }^{42}$ ), men totalbildet av $\phi$ konomenes forskning synes ikke å ha endret seg vesentlig i de mellomliggende år.

Når det gjelder den fremtidige utvikling av forskningen, mener Silver at i motsetning til det som var situasjonen for få år siden, er den største hindring for $\varnothing$ ket kunnskap om kriminell adferd ikke lenger mangelen av forfinede teoretiske modeller, men mangelen på sikre data. Ettersom man får mer data f. eks. om virkelig i motsetning til registrert kriminalitet, om subjektive oppfatninger om straffens visshet og strenghet i stedet for den objektive visshet og strenghet, og om kriminaliteten og dens utvikling innenfor enkelte befolkningsgrupper, mener han det vil bli mulig å gjøre n $\varnothing$ yaktige forutsigelser og prøve hypoteser om

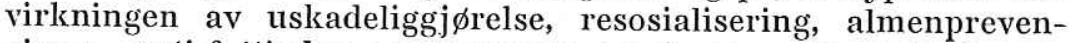
sjonen, anti-fattigdomsprogrammer og så videre. Derved vil man også få grunnlaget for meningsfylte kriminalpolitiske forslag.

Jeg har vanskelig for å føle meg overbevist av denne optimisme. En ting er at de data Silver taler om kan være meget vanskelige og kostbare å få tak i. Heller ikke har man funnet noen overbevisende metode til å skille mellom den almenpreventive og den uskadeliggjørende virkning av fengselsstraffen. Det er også vanskelig å tenke seg at de kvantitative sammenhenger man

40) Ehrlich (1973) s. 556-559.

41) Morris Silver (se note 35 ovenfor) s. 30.

${ }^{42}$ ) Kenneth Avio og C. Scott Clark, Property Crime in Canada: An Econometric Study (Toronto 1976). 
finner, vil være de samme i stater med hфyst forskjellig sosial sammensetning og kulturtradisjon, og at de vil holde seg konstante over tid i et samfunn i rask forandring. Kanskje enda viktigere er det at problemet med å avgjøre om korrelasjon betyr kausalitet, bare synes delvis $1 \phi$ st. Jeg kan f. eks. ikke se hvordan den mulige virkning av det normative klima kan elimineres.

I et tidligere arbeid har jeg uttalt om sammenligninger mellom geografiske områder: „For å kunne trekke avgjørende slutninger trenger man områder med likeartede sosiale forhold, men drastiske forskjelligheter i rettssystemet, og slike sammenligningsmuligheter byr seg sjelden." ${ }^{43}$ ) Dette var antakelig en undervurdering av de muligheter som moderne statistiske metoder gir. Men for en ikke-statistiker sitter det likevel igjen en nagende tvil om hvor meningsfullt det kan være å sammenligne enheter som er så fundamentalt forskjellige som f. eks. jordbruksstatene Syd- og Nord-Dakota og stater som er dominert av storbyområder.

F $\phi \mathbf{r}$ jeg forlater den komparative forskning, vil jeg nevne to begrensninger som gjelder både for de sosiologiske og de $\phi$ konometriske arbeider av denne art. Hele denne forskning har vært begrenset til den tradisjonelle kriminalitet som omfattes av de federale „Uniform Crime Reports“. Betydningsfulle områder som narkotikaforbrytelser og hele registret av hvitsnippforbrytelser faller utenfor. Man kan ikke overf $\varnothing$ re resultatene fra den tradisjonelle kriminalitet til slike forbrytelser, og det vil være vanskelig å finne materiale for tilsvarende komparative unders $\phi$ kelser for deres vedkommende.

En annen innebygget begrensning, som har særlig betydning for våre nordiske land, er denne: De komparative unders $\phi$ kelser utnytter forskjeller i strafferettssystemet i forskjellige geografiske områder. I USA synes det å være så store forskjeller i måten systemet fungerer på, både mellom enkeltstatene innbyrdes og mellom områder innenfor samme stat, at de kan utnyttes som grunnlag for forskning om virkning av forskjellene.

Slike forskjeller, iallfall innenfor den enkelte stat, kan ses på som en ufullkommenhet ved systemet. I et perfekt system ville det for straffutmålingens vedkommende ikke være noen forskjell mellom distriktene. Var det strengere straffer i et distrikt enn i et annet, måtte det skyldes at det var mer av grov kriminalitet i det f $\not$ rste. I de nordiske land er dette langt på vei forholdet. Straffutmålingen i forskjellige distrikter innenfor det enkelte land er tilnærmet ensartet. Forskjeller mellom distriktene i straffutmålingens strenghet vil være så små og tilfeldige at man ikke kan regne med at de har målbare virkninger for kriminaliteten. Ideelt sett burde det samme gjelde med hensyn til viss-

43) Andenæs, Straff og lovlydighet s. 65 . 
heten av straffen. Det synes rasjonelt å fordele ressursene slik at oppdagelsesfrekvensen blir omtrent den samme overalt, men vanskelighetene ved en rask tilpasning til vekslende forhold medf $\phi$ rer at forskjellene her blir st $\varnothing$ rre. Oppklaringsprosentene for forskjellige politidistrikter i Norge varierte i 1975 mellom 20 (Oslo) og 61 (Vest-Agder). Her skulle altså mulighetene for komparative unders $\varnothing$ kelser av amerikansk type være større. Jo mer perfekt - $\mathrm{i}$ betydningen ensartet - et system virker, desto vanskeligere vil det være å finne bevis for noen almenpreventiv virkning gjennom komparative unders $\varnothing$ kelser.

Selv om man har betydelige forskjeller mellom geografiske områder å gå ut fra, er det en krevende oppgave å planlegge en komparativ unders $\phi$ kelse og tolke resultatene. Det kreves en h $\varnothing \mathbf{y}$ grad av innsikt i statistiske metoder, godt kjennskap til kriminologiske fakta og teorier, og ikke minst kunnskap om hvordan rettsmaskineriet fungerer og statistikkens tall blir til. Siden man ikke kan vente at all denne innsikt skal være samlet hos. noen enkeltperson, er det n $\phi$ dvendig med et teamwork, hvor hvert medlem av teamet er tilstrekkelig kjent med de andre aspekter av problemet til å delta i en fruktbar utveksling av idéer og synspunkter.

\section{Undersфkelser om virkningen av endringer $i$ lov eller håndheving.}

Den mest direkte metode til å utforske virkningene av endringer i lovgivning eller praksis er unders $\varnothing$ kelser „f $\not \mathbf{r}$ og etter“. Det burde være et rimelig krav at ingen vesentlige endringer i lovgivning eller praksis blir foretatt uten at det blir gjort fors $\phi \mathbf{k}$ på å kartlegge virkningene av endringen. Men oppgaven er ikke så enkel som det umiddelbart kan synes.44) For det første har man vanskeligheten med å skille ut virkningen av endringen blant alle de andre faktorer som har virket på samme tid. Bare plutselige og betydelige forandringer kan ventes å gi klart statistisk bevis for virkningen av endringene, og man $b \phi r$ ha store tall å regne med for at ikke tilfeldigheter skal spille inn. Det finnes også mange andre fallgruber. En er det som betegnes som tilbakevending til det normale (regression to mean). En endring i lovgivning eller praksis kan være svar på en $\phi$ kende kriminalitet. Hvis så kriminaliteten går ned etter endringen, ligger det nær å

44) De metodiske problemer er utførlig diskutert hos Zimring og Hawkins s. 270-291; Donald T. Campbell, Reforms as Experiments. American Psychologist Vol. 24 (1969) s. 409; Donald T. Campbell og H. Lawrence Ross, The Connecticut Crackdown on Speeding: Time Series Data in Quasi-Experimental Analysis. Law and Society Review Vol. 3 (1968) s. 33. 
tolke dette som en virkning av denne, mens studiet av en lengre tidsserie kanskje viser at det som har hendt er en tilbakevending til et mer normalt nivå, som kanskje ville ha inntrådt også uten endringen. En annen feilkilde henger sammen med det store omfang av uanmeldt og uregistrert kriminalitet. Den publisitet som en endring i lov eller praksis er gjenstand for, kan påvirke tilbøyeligheten til å anmelde det lovbrudd det gjelder, og derved g.jøre utviklingen av de registrerte kriminalitetstall til et misvisende mål for den virkelige utvikling. Denne vanskelighet kan til en viss grad overvinnes ved at det blir foretatt omhyggelige sp $\phi$ rreskjemaunders $\phi$ kelser hos mulige of re (viktimiseringsstudier) for å kartlegge det virkelige omfang av vedkommende kriminalitetstype $f \phi r$ og etter endringen. I andre tilfelle kan man finne et mål for virkningen som er uavhengig av den offisielle kriminalstatistikk, f. eks. utviklingen av trafikkulykkesstatistikkens tall etter endringer i trafikklovgivningen.

Jeg skal nevne noen få viktige f $\varnothing \mathbf{r}$-og-etter studier fra de senere år.

Barry Schwartz unders $\phi$ kte virkningen i Philadelphia av forhøyede straffesatser for voldtekt. ${ }^{45}$ ) Bakgrumnen for straffeskjerpelsen var et usedvanlig brutalt tilfelle av voldtekt som rystet Philadelphia palmes $\phi$ ndag 1966 . Tre menn br $\phi$ t seg inn i et hus, voldtok og mishandlet en enke på 80 år, hennes datter på $4.4 \mathrm{og}$ hennes datterdatter på 14 år. Etter voldtekten ble huset gjennoms $\phi k \mathrm{kt}$ og plyndret. Bestemoren d $\phi$ de senere av skadene. De lovgivende myndigheter reagerte raskt med å forh $\phi y e$ straffesatsene for voldtekt; både demokratene og republikanerne pr $\phi$ vde å utnytte situasjonen politisk med sikte på de forestående valg i mai. Man kan vel gjette at reaksjonen hadde noen sammenheng med at gjerningsmennene i palmes $\phi$ ndagsvoldtekten var sorte og

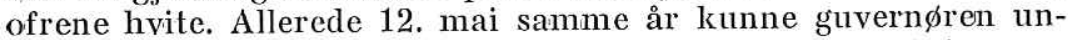
dertegne loven. For voldtekt uten legemsskade ble maksimumsstraffen hevet fra 15 til 20 år; for voldtekt med legemsskaide ble maksimum forh $\varnothing$ yet fra 15 år til livsvarig og det ble fastsatt en minimumsstraff på 15 års fengsel. Under forberedelsen av loven ble det gitt uttrykk for store forventninger med hensyn til den avskrekkende effekt på potensielle voldtektsforbrytere.

Så langt var det, for USA å være, ikke noe usedvanlig ved begivenhetsm $\varnothing$ nsteret. Det som var usedvanlig, var at det ble gjort et alvorlig fors $\phi k$ på å kartlegge virkningen av den nye lov. Tallenes tale var klar nok. I månedene etter at loven var gitt, hadde man de vanlige variasjoner $\mathrm{i}$ voldtektstallene fra måned

15) Barry Schwartz, The Effect in Philadelphia of Pennsylvania's Increased Penalties for Rape and Attempted Rape. Journal of Criminal Law and Criminology Vol. 59 (1968) s. 509. 
til måned, men ikke endringer som tydet på en nedgang som følge av den nye lov eller den publisitet som den hadde vært omgitt med. Schwartz er meget forsiktig i sine vurderinger, han foretar ingen store generaliseringer, men nфyer seg med à konstatere at „vi må trekke den konklusjon at Pennsylvania's nye avskrekkingsstrategi mot voldtekt var mislykket for så vidit angår Philadelphia“.

Det er flere punkter man kan peke på som tilsier forsiktighet med å trekke mer vidtgående slutninger. (1) Unders $\phi$ kelsen gjelder utelukkende korttidseffekten av den nye lov. Den utelukker ikke muligheten av en langtidsvirkning (selv om jeg anser det lite rimelig å anta at det skulle foreligge slike virkninger av noen betydning). (2) Den nye lov forandret straffesatsene, men vi vet ikke noe om hvilken betydning dette har hatt for den faktiske straffutmåling. (3) Vi vet ikke om den opphisselse og den publisitet som palmes $\phi$ ndagsvoldtekten og den følgende skjerpelse av lovgivningen var gjenstand for, har ledet til en $\phi$ kt tendens hos voldtektsofrene til à anmelde forbrytelsen. Hvis dette er tilfellet, ville uforandrede tall på anmeldite voldtekter bety et mindre antall av for $\varnothing$ vede voldtekter. Siden amerikanske viktimiseringsstudier tyder på at bare en av fire voldtekter blir meldt til politiet $\left.^{46}\right)$, kan en endring av ofrenes innstilling til anmeldelse lett skjule endog en betydelig avskrekkende effekt.

Til tross for disse teoretiske muligheter gir unders $\varnothing$ kelsen støtte for den oppfatning at for en forbrytelse som voldtekt kan det ikke ventes at en skjerpelse av de allerede meget strenge straffetrusler, vil bety noe vesentlig i almenpreventiv retning. Ut fra alminnelig psykologisk resonnement virker det også rimelig at det må være en meget liten gruppe som ikke lar seg avskrekke av en trusel om 15 års straff, men lar seg avskrekke av truselen om 20 års straff. Men det er ikke berettiget å generalisere fra dette til andre typer av forbrytelser og andre nivå av straff. Det ville være en feilslutning av samme art som tidligere generaliseringer fra unders $\phi$ kelsene om virkningen av d $\varnothing$ dsstraff for drap.

Andre nyere studier gjelder det viktige sp $\phi r$ smål om virkningen av straffetrusler for f $\varnothing$ rerens adferd i trafikken. ${ }^{47}$ ) Chambliss intervjuet universitetslærere for å finne ut hvordan de reagerte på en $\varnothing$ kning av bøtene og en strengere håndhevelse av parke-

46) Task Force Report. Crime and its Impact. An Assessment. The President's Commission on Law Enforcement and Administration of
Justice (1967) s. 119-120.

47) En fortrinnlig drøftelse av tidligere unders $\emptyset$ kelser er gitt av Roger C. Cramton, Driver Behavior and Legal Sanctions: A Study of Deterrence. Michigan Law Review Vol. 67 (1969) s. 421. 
ringsbestemmelser på et universitetsområde. ${ }^{48}$ ) Han fant, og det kan vel knapt overraske, at for noen av universitetslærerne hadde strengheten og vissheten av sanksjonen betydning for deres adferd. Den viktigste og best studerte erfaring med straffebestemmelser for å bekjempe u $\not$ nsket $\mathrm{f} \phi$ reradferd, gir den britiske Road Safety Act fra oktober 1967, som gjorde det straffbart å kjøre motorvogn med mer enn 0.8 promille alkohol i blodet. ${ }^{49}$ ) Etter de tidligere bestemmelser var det ingen fast promillegrense, og i praksis ble det bare domfellelse i tilfelle av sterk beruselse. Straffen for f $\phi$ rste gangs overtredelse etter loven av 1967 er normalt en bot og inndragning av kjørekortet for elt år. Den nye lov ble ledsaget av en intens publisitetskampanje, som ble satt $i$ gang to uker f $\phi \mathrm{r}$ loven trådte $\mathrm{i}$ kraft $\mathrm{og}$ varte året ut. Fra den dag den nye lov trådte i kraft, inntraff et betydelig fall i trafikkulykker sammenlignet med de foregående år. For de f frste tre måneder var tallet på ulykker med personskade $16 \%$ lavere enn for det foregående år, og d $\phi$ dsfall i trafikken gikk ned med $23 \%$. Særlig talende var tallene for sene kvelds- og nattetimer, weekender og juledager, kort sagt de tider da kombinasjonen av alkoholnytelse og motorvognkjфring er mest vanlig. Mellom kl. 20 og kl. 4 var nedgangen i ulykker sammenlignet med de samme måneder foregående år $36 \%$ i oktober, $38 \%$ i november og $41 \%$ i desember. Andelen av omkomne f $\phi$ rere som hadde blodalkohol over lovens grense, sank fra $25 \%$ til $15 \%$. Kort sagt: Det kunne ikke være noen rimelig tvil om at loven hadde en betydelig effekt på f $\phi$ reradferd og trafikkulykker. Trafikkministeriet kunne med stolthet regne ut hvor mange $d \phi d s f a l l$ og hvor mange tilfelle av personskade loven hadde hindret. Siden opinionsmålinger f $\phi \mathbf{r}$ og etter lovens ikrafttreden viste at det ikke var inntrådt noen nevneverdig endring $\mathrm{i}$ innstillingene til alkohol og motorvognkjøring; ${ }^{50}$ ) må resultatet $i$ alt vesentlig betraktes som en ren avskrekkelsesvirkning.

Beklageligvis ser det ut til at mesteparten av virkningen var gått tapt igjen ved utgangen av 1970. Det er det resultat Ross kommer til ved sin drøftelse av trafikkulykkesstatistikken, og

48) William J. Chambliss, The Deterrent Influence of Punishment. Crime and Delinquency Vol. 12 (1966) s. 70; Types of Deviance and the Effectiveness of Legal Sanctions. Wisconsin Law Review Vol. 67 (1967) s. 703.

49) En detaljert og informativ diskusjon av loven, dens gjennomf $\phi$ ring og virkninger er gitt av $H$. Lawrence Ross, Law, Science, and Accidents: The British Road Safety Act of 1967. Journal of Legal Studies Vol. 2 No. 1 (1973). Ogsa trykt i Research Contributions of the American Bar Foundation 1973 No. 1. Se også Andenæs, Straff og lovlydighet s. 86-94 og i Lov og Rett 1975 s. 222.

50) Se foran ved note 13. 
selv om de offisielle kommentarer til statistikken ikke helt deler hans oppfatning, virker hans bevisf $\varnothing$ rsel overbevisende. Et vilktig indisium er at andelen av drepte motorvognf $\phi$ rere med mer enn 0.8 promille var steget igjen til de samme $25 \%$ som f $\phi \mathrm{r}$ loven. I 1974 var tallet endog steget til $35 \% .{ }^{51}$ )

Den viktigste forklaring for denne utvikling finner Ross i svak håndhevelse av reglene. Publisiteten omkring loven hadde gitt publikum overdrevne og helt urealistiske forestillinger om risikoen for oppdagelse og straff. Men det ble gjort lite for å håndheve loven; politiet oppfattet ikke håndhevelsen som en viktig oppgave, og publikum lærte at de hadde overvurdert risikoen. Den beste sjanse til å gjenopplive virkningene av loven ville derfor, mener Ross, være å forandre politiets praksis. ${ }^{52}$ )

Erfaringene med den britiske promillelov har vist at det er mulig, iallfall på et praktisk viktig område som dette, å endre adferd ved trusel om straff, men også at man ikke kan vente at resultatet skal holde seg hvis håndhevelsen ikke er tilstrekkelig effektiv til å gjøre truselen troverdig. Viktige er også de metodiske lærdommer. Når man i dette tilfelle har kunnet trekke så sikre slutninger om lovens virkninger, skyldes det i f $\phi$ rste rekke at man i trafikkulykkesstatistikken har hatt en objektiv målestokk for virkningene, at man har hatt en detaljert og spesifisert statistikk $f \varnothing r$ og etter loven, og at man har operert med så store tall at mulige tilfeldigheter er utjevnet. Man har også fått demonstrert betydningen av å kombinere forskjellige metoder (trafikkulykkesstatistikk, unders $\varnothing$ kelser av blodalkohol hos omkomne f $\phi$ rere, og intervjuunders $\phi$ kelser ).

Ross har fors $\phi k$ t å unders $\phi$ ke virkningen på trafikkulykkesstatistikken av den norske promillelov av 1936 og den svenske av 1941, og siden han ikke er i stand til å finne noen utslag på ulykkestallene, trekker han i tvil den alminnelige oppfatning om effektiviteten av denne lovgivning. ${ }^{53}$ ) Dette er etter min mening å bygge for meget på en bestemt metode $\mathrm{i}$ en situasjon hvor man ikke kan vente at den kan gi noe svar. Da den norske og den svenske lov ble gitt, forelå ingen av de omstendigheter som gjorde det mulig å trekke slutninger fra ulykkesstatistikken, slik som for den britiske promillelov. I Norge var tallet på d $\varnothing$ dsulykker i

51) If $\phi$ lge opplysning av $H$. Laurence Ross, Deterring the Drinking Driver: A Critique of Blennerhassett. British Journal of Law and Society Vol. 3 (1976) s. 255 (se s. 256).

52) I en senere artikkel (sitert i forrige note) gir han imidlertid uttrykk for en viss skepsis med hensyn til hva man kan oppnå på lang sikt ad denne vei.

53) H. Laurence Ross, The Scandinavian Myth: The Effectiveness of Drinking-and-Driving Legislation in Sweden and Norway. The Journal of Legal Studies Vol. IV (1975) s. 285. 
trafikken i 1936 lavt (omtrent 100 om året), og de ble bare angitt i d $\varnothing$ dsårsaksstatistikken, uten oppgaver over hvordan ulykkene fordelte seg på ukedag og tid på døgnet. I motsetning til det som var tilfellet i England i 1967, ser det ikke ut til å ha vært noen st $\phi$ rre publisitet omkring vedtakelsen av loven; det er mulig at kunnskap om loven bare trengte gjennom gradvis. Man hadde ingen unders $\phi$ kelser av blodalkohol hos drepte f $\phi$ rere $f \phi r$ og etter loven, og ingen intervjuunders $\phi$ kelser om innstillinger til alkohol og motorvognkjøring. I Sverige i 1941 var situasjonen stort sett den samme, og i tillegg kom de endringer i trafikk- og ulykkesforholdene som skyldtes krigen. Under disse omstendigheter ville det ha vært forbausende om det hadde vært mulig å bevise noe om virkningen av den nye lovgivning ved analyse av trafikkulykkesstatistikken. Hvis en vesentlig del av virkningen av de nordiske lands promillelovgivning skyldes lovens innflytelse på den moralske innstilling til alkohol og bilkjøring, slik som mange mener, er dette noe som beror på en langtidsprosess, som man ikke kan lese ut av statistikken over d $\phi$ dsulykker. Det kan nok være grunn til å tvile på om f. eks. den strenge norske promillelovgivning, med ubetinget fengsel i minst 21 dager som normalstraff selv for den minste overskridelse av grensen, er så effektiv når det gjelder å hindre alkoholulykker som det gjerne har vært antatt, men tallene for d $\varnothing$ dsulykker i trafikken er ikke noe å bygge på i så måte. ${ }^{54}$ )

\section{Intervjuunders $\varnothing$ kelser.}

Intervjuunders $\phi$ kelser kan være av interesse på flere måter i studiet av almenprevensjonen. Den motiverende effekt av straffelov og rettshåndhevelse beror ikke på de objektive forhold, men på folks oppfatning av dem. Kommunikasjonsprosessen fra lovgiver og rettshåndhevende myndigheter til publikum er derfor et sentralt ledd i almenprevensjonens virkemåte. I eldre strafferettsteori ble det ikke lagt megen vekt på dette. Det ser ut som om man stilltiende gikk ut fra at det er samsvar mellom objektive realiteter og den enkeltes oppfatning. Kanskje var dette syn mer realistisk under eldre tiders enklere og mer statiske forhold enn i våre dager preget av kompleksitet, forandring og mobilitet, og en uopph $\phi$ rlig str $\phi \mathrm{m}$ av informasjon gjennom massemedia, hvorav bare en br $\phi$ kdel kan oppfattes og huskes.

At en forandring som ikke blir lagt merke til blant publikum, ikke får noen betydning for den almenpreventive virkning, er i og for seg en selvf $\varnothing$ lge. Et vel kjent finsk forskningseksperiment

54) Se nærmere Andenæs, The Effects of Scandinavia's Drinking-andDriving Laws: Facts and Hypotheses. Scandinavian Studies in Criminology Vol. 6 (under trykning). 
gir en god illustrasjon..$^{55}$ ) I tre finske byer av middels st $\phi$ rrelse samtykket politiet i å redusere antallet bøter for beruselse på offentlig sted fra $40-50 \%$ av drukkenskapsarrestantene til $10-$ $25 \%$. I tre liknende byer, som tjente som kontrollmateriale, ble praksis ikke forandret. Den reduserte bruk av bot syntes ikke å ha noen betydning for omfanget av offentlig beruselse, målt ved antallet drukkenskapsarrestasjoner. Ved deltakende observasjon og spфrsmål til politifolk ble det brakt på det rene at ikke engang de kroniske overtrederne hadde lagt merke til forandringen. De som slapp bot, priste bare sitt hell. At den reduserte bruk av bøter ikke hadde hatt noen virkning på antallet arrestasjoner, hadde derfor sin naturlige forklaring; endringen av politiets praksis hadde vært så lite synbar at den ikke engang ble lagt merke til av dem som den hadde st $\phi r$ st betydning for. - Eksperimentet ble ofte påberopt i den debatt som førte til at straffen for offentlig beruselse ble opphevet i Finland i 1969. Som Mäkelä påpeker, var dette å trekke st $\varnothing$ rre slutninger enn eksperimentet ga grumnlag for. ${ }^{56}$ ) En full opphevelse av straffen for offentlig beruselse kunne ikke godt gå upåaktet hen, slik som reduksjonen av antallet b $\phi$ teleggelser.

En av de best kjente og oftest siterte intervjuunders $\phi k$ kelser om publikums kjennskap til straffene for forskjellige forbrytelser, ble utf $\phi$ rt i California av Dorothy Miller og medarbeidere i en rapport til statens lovgivende forsamling. ${ }^{57}$ ) Forfatterne fant at menigmanns kjennskap til maksimumsstraffene var meget dårlig. $\mathrm{Og}$ de trakk vidtrekkende konklusjoner fra dette faktum. De starter med det som de selv karakteriserer som en grunnleggende forutsetning, og hevder med uthevet trykk: "Hvis straffer skal avskrekke, må forutsetningen vare at folk vet hva straffene er." Hovedtanken i unders $\phi$ kelsen er å vise at siden kjennskapet til straffene er så dårlig, kan de ikke virke avskrekkende. De fant at kriminelle kjenner bedre til straffene enn befolkningen ellers, og sluttet fra dette at st $\phi$ rrelsen av straffetruselen bare blir av interesse for en person etter at han selv har gjort seg skyldig $\mathbf{i}$ straffbart forhold. Straffetruslene virker ikke avskrekkende, men folk begår kriminelle handlinger og lærer så om de straffene som f $\varnothing$ lger med en kriminell karriere.

Selv bortsett fra at kunnskap om maksimumsstraffer sannsynligvis er mindre viktig enn kunnskap om de straffer som blir

55) Se nærmere Patrik Törnudd, The Preventive Effects of Fines for Drunkenness. Scandinavian Studies in Criminology Vol. 2 (1968) s. 109.

${ }^{56)}$ Klaus Mäkelä, Om straffens verkningar. Oikeustiede VI (1975) s. 237 flg. (se s. $266-268$ ).

57) Dorothy Miller, Ann Rosenthal, Don Miller og Sheryl Ruzek, Public Knowledge of Criminal Penalties: A Research Report (1968). Også trykt i Stanley E. Grupp, Theories of Punishment (1971) s. 205. 
anvendt i praksis, er slutningen åpenbart uholdbar. Det er nok sá at man må ha kjennskap til, eller iallfall anelse om, et straffebud for at det skal virke motiverende. Men når det gjelder straffesatsene, trenges ingen nøyaktig kunnskap. De fleste har en viss forestilling om alvoret ved de forskjellige forbrytelser og de ubehagelige konsekvenser som kan ventes i tilfelle av oppdagelse og domfellelse, og noe mer kreves ikke for at straffetruselen skal kunne virke motiverende. Om mer eksakt kunnskap ville $\phi$ ke eller minske denne virkning, beror på om vedkommende undervurderer eller overvurderer straffen. De tolkinger som Miller og medarbeidere gir av sine egne funn, er så ukritiske at det er vanskelig å forklare dem annet enn som utslag av den tradisjonelle motvilje blant kriminologer mot å anerkjenne almenprevensjonen som en realitet.

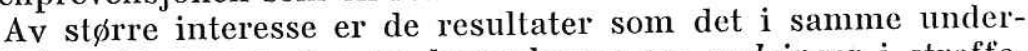
s $\phi$ kelse gjøres rede for om kunnskaper om endringer i straffesatsene. I 1967 hadde lovgivningen i California $\varnothing \mathrm{kt}$ straffene for voldtekt, ran og innbrudd med grov legemsskade til f $\phi$ lge. Minimum for disse forbrytelser ble satt til 15 års fengsel. Det store flertall av befolkningen var uvitende om disse endringer. Det illustrerer at vanskelighetene ved å få endringer i straffebudene kjent innebærer en begrensning i muligheten for å $\phi \mathrm{ke}$ den almenpreventive virkning ved en $\phi \mathrm{kning}$ av straffesatsene. Men det kan være grunn til å gjøre to bemerkninger til dette. (1). Kunnskapsnivået blant folk flest er ikke noe pålitelig mål for kunnskapen hos dem som trenger budskapet mest, de potensielle lovovertredere. Hvor meget en vanlig husmor eller en middelaldrende funksjonær kjenner til straffesatsene for ran eller innbrudd, er uten praktisk betydning for almenprevensjonen. Resultatene fra unders $\phi k$ kelsen tyder sterkt på at de grupper som representerer den st $\varnothing$ rste kriminalitetsrisiko, har best kjennskap til loven og endringer i den. Av de innsatte i fengsler for voksne ga $76 \%$ riktige svar på spørsmålet om straffen for ran med legemsskade til følge, og $65 \%$ av college-studentene ga riktige svar på spørsmålet om straffen for besittelse av marihuanal (hvor ingen forandring var gjort). (2). Siden folk flest sannsynligvis får sin kunnskap om straffelov og praksis gjennom reportasje om kriminalsaker, kan kunnskap om straffene sive inn i tidens $1 \phi$ p, selv om vedtagelsen av en ny lov har passert ubemerket. Som eksempel kan nevnes den norske promillelovgivning. Da loven ble gitt i 1936, var det ingen stor publisitet og det er usikkert hvor godt kjennskapet til loven var. Men en intervjuunders $\phi$ kelse i 1976 viste både et meget høyt kunnskapsnivå og et godt samsvar mellom lovens vurderinger og publikums vurderinger. Også her var kunnskapen st $\phi$ rst hos dem som trengte den mest. Den var st $\phi$ rre hos personer med 
enn uten f $\phi$ rerkort, og st $\phi$ rre hos dem som bruker alkohol enn hos dem som ikke gjør det (se foran ved note 14).

Loven og domstolspraksis gir informasjon om strengheten av reaksjonen, men det finnes ingen tilsvarende offisielle kilder som kan gi kunnskap om vissheten av reaksjonen. Sammenhengen mellom objektiv risiko og subjektiv risikof $\varnothing$ lelse er derfor svært komplisert. Den kriminologiske forsker kan, forutsatt at han har tall over anmeldelseshyppighet og oppklaringsprosenter, beregne gjennomsnitts risikotall for de enkelte forbrytelser. Unders $\varnothing$ kelser om uregistrert kriminalitet kan gi grunnlag for slike beregninger. Folk flest har ikke slike kilder til disposisjon, og det samme gjelder stort sett lovbryterne. Folk danner seg kanskje et visst inntrykk fra mange kilder: Folkelige forestillinger om forbrytelse og straff, lesning om forbrytelser som blir oppklart eller ikke oppklart, kjennskap til politirutiner osv. De fleste gjør seg sikkert lite tanker om spørsmålet, inntil det dukker opp en intervjuer fra et meningsmålingsinstitutt som vil ha deres syn. Og den som overveier å begå et lovbrudd, er ikke interessert i den gjennomsnittlige risiko, men i den risiko han selv vil m $\phi$ te. Hvis en person $\mathrm{f}$. eks. overveier å begå et innbruddstyveri, vil han tenke på risikoen for å bli hørt eller sett av naboer eller en tilfeldig forbipasserende, eller at det kan være installert alarmapparat $\mathrm{i}$ huset, eller at han senere kan bli identifisert ved fingeravtrykk eller på annen måte. $\mathrm{Og}$ han vil prøve å tilpasse sitt valg av gjerningssted og fremgangsmåte slik at den samlede risiko skal bli minst mulig. For den profesjonelt kriminelle kan slike forberedelser utgjøre en vesentlig del av arbeidet. ${ }^{58}$ )

En britisk unders $\varnothing$ kelse intervjuet unge menn mellom $15 \mathrm{og}$ 22 år om deres oppfatning av risikoen. ${ }^{59}$ ) De fleste av dem overvurderte sterkt risikoen for å bli tatt, når deres svar ble sammenliknet med gjennomsnittlige opplklaringstall ${ }^{60}$ ), men de mer kriminelt belastede var tilb $\phi$ yelig til å være mer optimistiske, det vil si mer realistiske, sier Nigel Walker. Han tar dette som utgangspunkt for noen spekulasjoner om muligheten av å senke

58) Se f. eks. beskrivelsen hos Peter Letkemann, Crime as Work (1973) s. $137-157$.

59) H. I. Wilcock og J. Stokes, Deterrents to Crime Among Youths Aged 15 to 21, her gjengitt etter Nigel Walker, Sentencing in a Rational Society (1969) s. 63-68.

60) Om der foreligger en overvurdering av risikoen $\mathrm{i}$ det individuelle tilfelle er vanskelig á si, siden risikoen i så høy grad avhenger av forsiktighet og dyktighet. Det er blitt sagt av en erfaren psykiater at en av de slående egenskaper ved lovovertredere er at de har „, en magisk tro på sin egen dyktighet, hell eller hva de nå kaller det — ofte i åpenlys kontrast til kjensgjerningene". Se Melitta Schmideberg, The Offender's Attitude Toward Punishment. Journal of Criminal Law, Criminology, and Police Science, Vol. 51 (1960) s. 332. 
kriminalitetstallene ved å $\phi \mathrm{ke}$ oppdagelsesrisikoen: „For innbruddstyverier (og de fleste andre vinningsforbrytelser) er dette et urealistisk håp. Oppklaringsprosenten er så lav at den er overvurdert av alle bortsett fra en liten minoritet. Å endre oppfatningene hos en realistisk minoritet ville kreve en enorm $\phi$ kning av politiets effektivitet, og å heve ytterligere de overdrevne forestillinger hos majoriteten, synes nesten helt utelukket.“61) Dette er kanskje for pessimistisk. Selv om de individuelle oppfatninger om risikoen avviker sterkt fra de beregnede objektive risikotall, er det vanskelig å tro at vesentlige endringer i den objektive risiko skulle være helt uten betydning for oppfatningene om risikoen. For å si det på en annen måte: Hvis folk overvurderer risikoen under de nåværende forhold, ville de kanskje fortsette å overvurdere risikoen i samme grad om den objektive oppdagelsesrisiko ble endret.

Spørsmålet om sammenhengen mellom virkelig og opplevd strenghet og visshet av straffen er åpenbart praktisk meget viktig. Det kan tenkes belyst ved komparative intervjuunders $\phi$ kelser, hvor oppfatningen hos publikum om strenghet og visshet $\mathrm{i}$ forskjellige områder sammenholdes med de faktiske forhold. Hvis man finner en $h \phi y$ grad av samsvar, vil det tyde på at informasjonsmangel ikke er noen avgjørende hindring for almenpreventive effekter. Skulle det derimot vise seg at publikumsoppfatningene om strenghet og visshet varierer uavhengig av de objektive forhold, for alle forbrytelser eller for noen av dem, ville det gi grunn til å se med skepsis på foreliggende forskningsresultater om virkningen av strenghet og visshet på kriminalitetstallene. Intervjuunders $\varnothing$ kelser vil således kunne være et viktig supplement til andre typer komparative studier. Slike unders $\phi$ kelser har så vidt jeg vet ikke vært foretatt.

Når det gjelder de moralske virkninger av straffetruslene deres betydning for folks innstillinger til de forbudte handlinger - er det tale om en langtidsprosess, som neppe kan kartlegges på annen måte enn ved intervjuunders $\phi$ kelser ${ }^{62}$ ) Intervjuunders $\phi$ kelser har bl. a. vært foretatt omkring britisk og norsk promillelovgivning, og har gitt interessante resultater selv om det ikke har vært tale om planmessige unders $\phi$ kelser over lengre tid (se foran ved note $13 \mathrm{og} 14$ ).

Ytterligere en måte å utnytte intervjuunders $\varnothing$ kelser på skal nevnes. I den utstrekning almenprevensjonen er en realitet, vil den enkeltes oppfatninger om reaksjonens strenghet og visshet spille en rolle for hans beslutning om å begå eller ikke begå en

61) Nigel Walker, op. cit. s. 75.

62) Således Ulla Bondeson, Survey Research as a Means to Explore General Deterrence. I konferanserapport General Deterrence s. 137. 
lovovertredelse. Den som tror at straffen er streng og risikoen stor, har sterkere grunner til å avholde seg fra lovovertredelsen enn den som har andre forestillinger. Det har vært foretatt en del unders $\phi k$ kelser hvor man har intervjuet grupper av lovovertredere (registrerte eller uregistrerte) om deres oppfatninger om risikoen og straffens st $\varnothing$ rrelse, og sammenliknet dette med svar på tilsvarende sp $\phi$ rsmål fra andre grupper. ${ }^{63}$ ) Visse sammenhenger er funnet. Stort sett er omfanget av lovovertredelser noe større hos dem som anser risikoen for lav enn hos dem som anser den for $h \phi y$; enkelte unders $\phi$ kelser finner også en viss sammenheng mellom den enkeltes oppfatning om straffens st $\phi$ rrelse og tendensen til å overtre loven. Det knytter seg imidlertid atskillig usikkerhet til tolkingen av resultatene. Ett problem gjelder tidsrekkef $\phi$ lgen. Hvis vi finner forskjeller mellom lovovertredere og ikke-overtredere $\mathrm{i}$ deres oppfatninger om risiko og straff, er det vanskelig å vite om disse forskjeller forelå f $\varnothing \mathbf{r}$ lovovertredelsen ble begått, og altså kunne ha betydning for motivasjonsmekanismen, eller om de skyldes lovovertredernes erfaring. Teevan har fors $\phi k$ t å m $\phi$ te denne innvending ved uttrykkelig å sp $\phi$ rre lovbryterne om hvilket syn de hadde på risikoen og straffens st $\phi$ rrelse $f \phi r$ lovbruddet, men det knytter seg naturligvis adskillig usikkerhet til påliteligheten av svarene på et slikt spфrsmål om psykologiske forhold i fortiden. Et annet problem er at lovbrytergruppen og de andre kan adskille seg på andre punkter, som har systematisk sammenheng med oppfatninger av risiko og straffens st $\phi$ rrelse, og derfor griper forstyrrende inn i resultatene. Den student som han venner som røker marihuana, blir rimeligvis påvirket av disse både når det gjelder oppfatningene om risiko og straffest $\varnothing$ rrelse og når det gjelder tilbøyeligheten til selv å fors $\varnothing$ ke seg.

Henshel har angrepet tidligere komparative unders $\varnothing$ kelser om almenprevensjonen fordi de ikke har tatt i betraktning det n $\varnothing \mathrm{d}-$ vendige bånd mellom straffesystem og avskrekkingsvirkning som publikumsoppfatningene utgjør. „Logikken synes å kreve at det meste av tidligere forskning om avskrekking enten må analyseres på ny (hvor dette fremdeles er mulig), tolkes meget snev-

${ }^{63}$ ) Se f. eks. Chiricos og Waldo, Perceived Penal Sanction and SelfReported Criminality: A Neglected Approach to Deterrence Research. Social Problems Vol. 19 (1972) s. 522; James J. Teevan, Jr., Subjective Perception of Deterrence (Continued). Journal of Research in Crime and Delinquency Vol. 13 (1976) s. 155; Ulla Bondeson, Survey Research as a Means to Explore General Deterrence, i konferanserapport General Deterrence (1975); Erickson, Gibbs og Jensen, The Deterrence Doctrine and the Perceived Certainty of Punishment. American Sociological Review Vol. 42 (1977) s. 305 . Se også Mäkelä, op. cit. s. $260-262$ med referat og kritikk av Chiricos og Waldo's unders $\varnothing$ kelse. 
rere enn forfatterne har tenkt seg, eller i noen tilfelle motvillig kasseres." ${ }^{\text {64 }}$ )

Dette ville være riktig hvis hovedinteressen i unders $\varnothing$ kelsene hadde ligget $\mathbf{i}$ å finne ut hvor effektiv almenprevensjonen kan være under forutsetning av fullstendig kunnskap hos almenheten, eller å finne ut hvor meget av denne potensielle effekt som går tapt på grunn av manglende kunnskap. Dette er spørsmål som er viktige nok. Men for lovgiveren og de rettshåndhevende myndigheter er det viktigste sp $\phi$ rsmål hva de kan oppnå i denne verden slik som den nå engang er. Ufullstendig kunnskap hos publikum om strafferettssystemet er noe som man må leve med og ta $\mathrm{i}$ betraktning. Forskning om virkningen av A (straffetruselen) på C (kriminalitetstallene) kan være gyldig nok selv om man ikke kjenner det mellomliggende ledd i kjeden (publikums oppfatninger) - på samme måte som virkningen av et medikament mot en sykdom kan unders $\phi$ kes uten at man er klar over virkningsmekanismene. En annen sak er at intervjuunders $\phi$ kelser om kunnskap og innstillinger kan bidra til å svekke eller styrke de resultater som man finner ved andre metoder, og også kan bidra til en bedre forståelse av selve prosessen.

\section{Eksperimenter.}

Eksperimenter av interesse for studiet av almenprevensjonen kan være av forskjellig art.

(1). Én type er de hvor f. eks. politi eller rettsvesen foretar en fors $\phi k$ svis endring $\mathrm{i}$ praksis nettopp for å studere virkningen av endringene. Dette er i virkeligheten f $\phi$ r-og-etter unders $\phi$ kelser som like gjerne kunne vært omtalt $\mathrm{i}$ avsnitt VI; det spesielle er

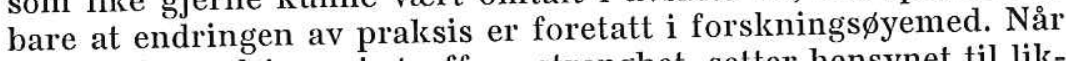
det gjelder endringer $\mathbf{i}$ straffens strenghet, setter hensynet til likhet og rettferdighet i rettspleien snevre grenser for muligheten av slike eksperimenter. Lettere er det å foreta eksperimentelle endringer i politiets praksis. Ett eksempel er det finske eksperiment med drukkenskapsbøter som er nevnt i foregående avsnitt. Andre eksperimenter har vært gjort for å belyse virkningen av forskjellige former for trafikkontroll, eller av en $\phi \mathrm{kning} i$ antallet patruljerende politifolk eller politibiler i et bestemt distrikt. ${ }^{65}$ ) Meget kjent og omtalt er det eksperiment som ble gjort i Kansas City 1973-1974 for å unders $\phi$ ke betydningen av end-

64) Richard L. Henshel, Deterrence and Knowledge of Sanctions, i R. L. Allers og E. Sagarin, Crime Prevention and Social Control (1974) s. 51 (se s. 59).

$\left.{ }^{65}\right)$ En oversikt over slike unders $\varnothing$ kelser er gitt av James $Q$. Wilson, Do the police prevent crime? The New York Times Magazine 6. okt. 1974, seksjon 6 . 
ringer i antallet patruljerende politibiler. Noen av politidistriktene $\mathrm{i}$ byen fikk $\mathrm{i}$ en eksperimentperiode på ett år $2-3$ ganger så mye bilpatruljering som det normale; for andre ble det slutt på all bilpatruljering - politibiler kom bare når de ble tilkalt. Resultatet var oppsiktsvekkende: Ved periodens utl $\varnothing$ p lot det til at endringene i patruljeringsintensiteten ikke hadde hatt noen betydning for omfanget av begåtte forbrytelser, og heller ikke for borgernes trygghetsf $\varnothing$ lelse. Resultatet f $\varnothing$ yer seg til andre undersøkelser som tyder på at politiet er lite effektivt når det ikke får hjelp ved anmeldelser eller andre henvendelser fra publikum. ${ }^{66}$ ) Iallfall ser rutinemessig bilpatruljering ut til å være en arbeidsinnsats som kaster lite av seg.

Jeg skal også referere en interessant studie av eksperimentkarakter som den hollandske professor Buikhuisen har utf $\phi r t$ i samarbeid med politiet. ${ }^{67}$ ) Buikhuisen er ytterst kritisk overfor bruken av offisiell kriminalstatistikk i forskning. Han s $\phi$ kte seg derfor ut en type lovovertredelse som var lett å observere, og valgte overtredelse av forbudet mot å kjøre motorvogn med nedslitte dekk. Forskningsopplegget var enkelt. Ved samarbeid mellom politiet og pressen ble det i Groningen under stor publisitet gjennomf $\phi r t$ en aksjon fra politiets side med kontroll av biler med nedslitte dekk. Som kontrollby ble valgt den lignende by Leeuwarden, hvor det ikke fant sted noe usedvanlig hverken fra politict eller pressen. $\mathrm{F} \phi \mathrm{r}$ eksperimentet hadde forskerteamet identifisert og notert flere hundre biler med nedslitte dekk parkert i gatene i de to byer. Etter aksjonen, som varte i to uker, ble de tidligere noterte biler opps $\phi$ kt på ny for å se hvor mange som hadde fått nye dekk. Resultatet var $54 \%$ fornyelse i Groningen sammenlignet med $27 \%$ i Leuwarden. Forskjellen tilskriver forfatteren den almenpreventive effekt av aksjonen. Strengt tatt er dette en forenkling. Publisiteten kan ha fått noen bileiere til å kontrollere sine dekk med tanke på slitasje, uten at det beh $\varnothing$ ver å være risikoen for kontroll og straff som er avgjørende.

Senere ble både de $54 \%$ lovlydige og de $46 \%$ ikke lovlydige intervjuet for å finne ut forskjeller mellom gruppene. En forskjell var naturlig nok at kjennskapet til politiaksjonen var st $\varnothing$ rre blant de lovlydige enn i den andre gruppen. Den siste gruppen talte flere unge, hadde mindre utdanning, og hadde eldre og mindre verdifulle biler som stort sett var i dårlig stand. Forfatteren beskriver medlemmene av denne gruppen som en slags marginale

$\left.{ }^{66}\right)$ Se f. eks. Ragnar Hauge og Harald Stabell, Politivirksomhet i et norsk landdistrikt. NTfK 1975 s. $269-286$ (se især sammenfatningen
s. $284-285$ ).

${ }^{67)}$ W. Buikhuisen, General Deterrence: Research and Theory. Abstracts on Criminology and Penology Vol. 14 (1964) s. 285 (også inntatt i konferanserapporten General Deterrence). 
bileiere: Bileiere som knapt har råd til å ha bil. Hans hypotese er at pengemangel i dette tilfelle er den viktigste grunn til at de har overtrådt forbudet: „Deres $\phi$ konomiske stilling gj $\phi \mathbf{r}$ dem på en måte immune overfor straffetruselen." Selv om det ikke spesielt er nevnt, kan også en personlighetsfaktor ha gjort seg gjeldende. Noen er mer likeglade og slurvete enn andre, og dette kan resultere både $\mathrm{i}$ dårlig vedlikehold av vognen og manglende reaksjon på truselen om kontroll og bot.

Buikhuisen anser det kontrollerte eksperiment som den eneste metode til å teste hypotesene om almenprevensjonen. Han mener hovedproblemet er å overtale kriminologer til å samle sine egne data i stedet for å stole på offisiell kriminalstatistikk. Han foreslår endog at tidsskriftredakt $\varnothing$ rer burde avskrekke forskere ved å si at de for fremtiden ikke vil akseptere noen artikkel basert på slike åpenbart mangelfulle data. Svakheten ved dette utgangspunkt er at det er få områder, og iallfall få viktige områder, hvor kontrollerte eksperimenter kan gjennomf $\phi$ res innenfor rammen av strafferettspleien.

Som en slags eksperiment kan en også karakterisere det sanksjonsl $\varnothing$ se bilbeltepåbud som ble innf $\phi$ rt i Norge med virkning fra 1. september 1975. Man $\phi$ nsket å pr $\phi$ ve hvor langt selve lovens autoritet sammen med opplysning og propaganda kunne rekke, og forutsetningen var at sp $\varnothing$ rsmålet om sanksjon for overtredelse skulle tas opp på ny etter en prøvetid..$^{68}$ ) Når man valgte ordningen med påbud uten noen sanksjon mot overtredelse, var det nok delvis for å svekke de innvendinger som ble anf $\phi$ rt mot denne nye frihetsinnskrenkning. I juni 1977 vedtok Stortinget å forlenge prøvetiden med ett år, til tross for at resultatene etter 18 måneders pr $\varnothing v e t i d$ og en informasjonsinnsats for 6 millioner kroner, fra flere hold ble karakterisert som skuffende. Tellinger viser at i l $\varnothing$ pet av de 18 måneder er bruksprosenten utenfor tettbygd str $\phi k$ k kt fra 40 til 58 og innenfor tettbygd str $\phi k$ fra 15 til 26. Etter en betydelig oppgang i bruken straks etter at påbudet ble gitt, kom det en nedgang og etter hvert til en stabilisering. (Da påbudet ble innf $\phi$ rt, var det angitt som mål å komme opp i en bruksprosent for landet som helhet på 75). Siden det her er tale om en overtredelse som er forholdsvis lett å konstatere, kan det neppe være noen tvil om at en $\phi$ konomisk sanksjon for overtredelse ville $\phi$ ke bruksprosenten betydelig, noe som også st $\varnothing$ ttes av erfaringene fra andre land. I Sverige $\phi k t e$ f. eks. bruksprosenten fra 30 til 80 da man i 1975 i stedet for å fortsette å basere seg utelukkende på opplysning og propaganda, innførte et påbud

68) Se Ot.prp. nr. 46 (1974-75), Innst. O. nr. 63 (1974-75) og Ot. forh. $1974-75$ s. $602-619$. Se også St.meld. 88 (1976-77) om erfaringene. 
med bot for overtredelse. Det er neppe for dristig å anta, selv uten st $\phi$ tte i foretatte intervjuunders $\varnothing$ kelser, at et sanksjonsl $\varnothing$ st påbud på dette område psykologisk sett av de fleste ikke oppfattes som et virkelig påbud.

(2). I motsetning til eksperimenter som finner sted innenfor rammen av det eksisterende strafferettssystem, står det tradisjonelle laboratorieeksperiment om virkningen av straff på mennesker og $\mathrm{dyr}^{.69}{ }^{60}$ Det er foretatt en mengde slike eksperimenter, men de er oftest så langt fra situasjonen i det virkelige liv at de har liten relevans for vårt problem. ${ }^{70}$ ) Psykologene har som regel vært interessert $i$ virkningene av aktuell straff, ikke $i$ virkningene av en straffetrusel. For at en straffetrusel skal virke, kreves en viss evne til å tenke abstrakt og innrette seg etter fremtidige muligheter. Virkningen av lovens straffetrusel på en person som overveier å begå en straffebelagt handling, har lite eller ingenting til felles med virkningen av elektriske sjokk eller andre „straffer" på et fors $\phi$ ksdyr som foretar en viss adferd, f. eks. å trykke ned en vektstang eller hakke på en tallerken. Jeg tror trygt man kan si at dyrepsykologiske fors $\phi \mathrm{k}$ ikke kan gi noe nevneverdig bidrag til studiet av straffens almenpreventive virkning. Heller ikke den psykologiske forskning om virkningen av straff på mennesker synes å ha meget å gi i denne sammenheng. Lovens straffetrusel har særtrekk som skiller den sterkt fra vanlige eksperi-

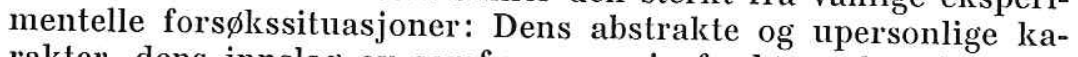
rakter, dens innslag av samfunnsmessig ford $\varnothing$ mmelse, de drastiske sanksjoner som den truer med ved grovere lovovertredelser. Også de interessante og velkjente eksperimenter som Milgram har foretatt om lydighetens psykologi, ${ }^{71}$ ) har derfor liten eller ingen relevans for problemet om straffelovens almenpreventive virkning.

(3). Som en tredje kategori har vi eksperimenter som er arrangert spesielt for å pr $\phi \mathrm{ve}$ teorier om almenprevensjonen, og hvor forholdene derfor er lagt til rette med sikte på å muliggjøre analogislutninger til det virkelige liv. Det er ikke meget som er gjort $\mathrm{i}$ denne retning, men en forholdsvis ny unders $\phi$ kelse av

69) En interessant oversikt er gitt av Barry $F$. Singer, Psychological Studies of Punishment. California Law Review Vol. 58 (1970) s. 405.

70) Se den stringente drøftelse hos Paul E. Meehl, Law and the Fireside Inductions: Some Reflections of a Clinical Psychologist. Journal of Social Issues Vol. 27 (1971) s. 85-89; Andenæs, Psykologisk forskning og teoriene om almenprevensjonen, i Straff og lovlydighet s. 143-

71) Stanley Milgram, Behavioral Study of Obedience. Journal of Abnormal and Social Psychology Vol. 67 (1963) s. 371-378; samme, Some Conditions of Obedience and Disobedience to Authority. Human
Relations Vol. 18 (1965) s. 57-76. 
Tittle og Rowe fortjener å nevnes. ${ }^{72}$ ) Tre sosiologiklasser fikk en serie på åtte ukentlige sp $\phi$ rsmålspr $\phi v e r$, som hver ga maksimalt ti poeng. Etter at de riktige svar var blitt forklart, ble studentene betrodd å beregne sine egne karakterer. Etter den fjerde prøven ble de to eksperimentgruppene minnet om at de var blitt vist den tillit at de ville bed $\phi$ mme sine pr $\phi$ ver ærlig, og at de hadde en moralsk forpliktelse til å være n $\phi y$ aktige. Etter den syvende proven ble de fortalt at det var blitt klaget over fusk, og at det derfor var n $\phi$ dvendig for læreren å foreta stikkpr $\phi$ vekontroll av noen av provene for å se om bed $\phi$ mmelsen var n $\phi$ yaktig. F $\phi$ r studentene skulle vurdere sin siste pr $\phi \mathrm{ve}$, ble de forklart at stikkpr $\phi$ vene hadde avsl $\phi \mathrm{rt}$ et tilfelle av fusk, og at vedkommende ville bli straffet. I virkeligheten hadde læreren, uten at studentene visste det, bed $\phi \mathrm{mt}$ svarene på alle pr $\phi$ ver f $\phi \mathrm{r}$ de ble overlatt studentene til egen gradering. Resultatene av unders $\phi$ kelsen kan sammenfattes slik: Det var en betydelig grad av fusk hele tiden; bare fem av 107 avholdt seg totalt fra fusk $i$ hele pr $\phi$ veperioden. Den moralske appell etter den fjerde pr $\phi$ ven hadde ingen påviselig virkning på omfanget av fusk. Truselen om å bli kontrollert og straffet hadde en påtakelig virkning, og denne virkning ble forsterket ved meddelelsen om at en som hadde fusket, var avslørt og ville få straff. Kvinnelige studenter ble langt sterkere påvirket av straffetruselen enn de mannlige. $\mathrm{Og}$ de studenter som trengte poeng mest, ble minst påvirket av truselen om straff; det ser ut til at deres motivasjon for å fuske var så stor at de var villige til å ta større risiko.

\section{Almenprevensjon, politikorrupsjon og organisert kriminalitet.}

I USA er politikorrupsjon og organisert kriminalitet problemer som gir grunnlag for stor bekymring. Korrupsjon i politiet kan naturligvis forekomme uten organisert kriminalitet. En politimann tar f. eks. imot en gave til gjengjeld for at han lukker $\phi y n e-$ ne for et lovbrudd. På den annen side kan organisert kriminalitet eksistere uten korrupsjon i politiet. Men normalt går de to ting sammen. Den amerikanske presidents Crime Commission uttalte i sin innstilling: ,Alle tilgjengelige data indiserer at organisert kriminalitet bare blomstrer der hvor lokale tjenestemenn er blitt korrumpert." ${ }^{\text {73) }}$ Andre komitéer er kommet til samme konklusjon. Politikorrupsjonen i USA er ofte ledd i et vidtforgrenet korrupsjonsnett, hvor hverken politikere, påtalemyndig-

${ }^{22}$ Charles R. Tittle og Alan R. Rowe, Moral Appeal, Sanction Threat, and Deviance: An Experimental Test. Social Problems Vol. 20 (1973) s. 488.

${ }^{73}$ ) Task Force Report: Organized Crime. The President's Commission on Law Enforcement and Administration of Justice (1967), se s. 6. 
het eller dommere har rene hender. Jo mer utbredt korrupsjonen er, dess vanskeligere er den naturligvis å komme til livs. Den som rapporterer om korrupsjonen, gir kanskje, uten å være klar over det, rapport til en som selv er med i nettet.

Enda så meget det er skrevet om politikorrupsjon og organisert kriminalitet, er emnet ikke trukket inn i den generelle diskusjon om almenprevensjonen. De to fenomener representerer den mest åpenbare svikt av straffelovens almenpreventive virkning. Men sett fra en annen side illustrerer de på en overbevisende måte den almenpreventive virkning som strafferettssystemet har når det virker som det skal. Hva er grunnen til at organisert kriminalitet vanligvis bare blomstrer $\mathrm{i}$ forbindelse med korrupsjon blant lovens håndhevere? Svaret er åpenbart at korrupsjonen innenfor politi og andre myndigheter lammer rettshåndhevelsen og gir de yrkeskriminelle en følelse av immunitet overfor rettsforfølgning og straff. Også den som nødig svarer ja på spørsmålet om straffeloven har en avskrekkende virkning, vil vanskelig bestride at en slik n $\phi$ ytralisering av straffetruselen gir grunnlag for en $\phi \mathrm{kning}$ av kriminaliteten. Hvilket bare er et annet uttrykk for at en straffetrusel som det står realitet bak, har en avskrekkende virkning.

Den organiserte kriminalitet har også en annen metode til å skape immunitet mot straff. Straffeloven er et system av trusler. De kriminelle organisasjoner skaper sitt eget system av trusler for å holde disiplin innenfor organisasjonen og avskrekke mulige angivere og vitner utenfor organisasjonen. Dette system av straffetrusler konkurrerer med lovens, og er ofte mer effektivt fordi det er mer hensynsl $\phi$ st og ikke hemmet av juridiske formaliteter og beviskrav. Reaksjonen er hurtig, streng og sikker, slik som klassisk avskrekkingsteori krevde. En amerikansk bok om narkotikaproblemet refererer følgende uttalelse fra en narkotikaselger til statsadvokaten, som pr $\phi v d e$ å få opplysninger om de h $\phi$ yere ledd i omsetningskjeden. „Vel, hva kan De gjøre? De kan gi meg noen år. Jeg har sittet inne f $\phi$ r. De kan gi meg fengsel. Hvis jeg sladrer og det blir kjent, er jeg d $\phi \mathrm{d}$ f $\phi \mathrm{r}$ uken er omme.“"74) Det ser ut til at gangsterorganisasjonene i USA bruker vold på en mer $\phi$ konomisk måte enn f $\phi \mathrm{r}$. Gangsterkrig og massedrap hører fortiden til. Nå spiller de på frykten, og begrenser seg til enkelte tilfelle av drap eller vold for at alle skal forstå hva de risikerer. Det er mange vitnesbyrd om at dette truselsystemet er effektivt. ${ }^{75}$ )

74) A. R. Lindesmith, The Addict and the Law (1965).

${ }^{75}$ ) Se f. eks. Mark H. Furstenberg, Violence and Organized Crime, inntatt i Vol. 13 Appendix 18 av Crimes of Violence, A Staff Report Submitted to the National Commission on the Causes and Prevention of Violence (1969). 


\section{Oppsummering: Hvor står vi $i$ dag?}

I tidligere diskusjon om almenprevensjonen var man henvist til å bygge på usystematisert erfaring, alminnelig psykologisk resonnement, introspeksjon og historisk materiale. Kan man si at de siste 10 års forskning har medf $\phi$ rt noen grunnleggende endring i situasjonen?

Det er ikke lett å gi noe klart svar.

Sikkert er det at sakligheten og det vitenskapelige nivå i diskusjonen er $\phi$ kt. Det er vanskeligere enn f $\phi \mathrm{r}$ a bli tatt alvorlig innenfor fagkretser med trosbekjennelser på emosjonelt grunnlag. Det har væert en vekselvirkning mellom empiri og teori. Forskningsresultatene og diskusjonen om deres holdbarhet har

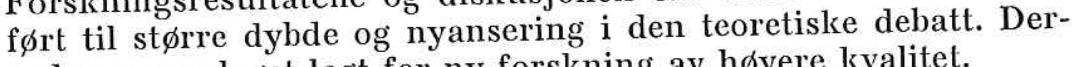
ved er grunnlaget lagt for ny forskning av hфyere kvalitet.

Det er også blitt vanskeligere å innta ekstreme standpunkter uten å komme i strid med det foreliggende forskningsmateriale. På den ene side lar det seg ikke godt gjøre å benekte realiteten av straffebestemmelsenes almenpreventive virkning, eller å hevde at virkningen er uavhengig av en effektiv håndheving. Erfaringene med den engelske promillelovgivning er her særlig instruktive. På den annen side tilsier de unders $\varnothing$ kelser som er gjort om kunnskaper om og innstillinger til strafferettssystemet en viss skepsis med hensyn til virkningen av mindre endringer i systemet. Troen i enkelte kretser på at en $\phi$ kning av straffesatser eller av politiinnsats automatisk f $\varnothing$ rer til lavere kriminalitet, fremstår som klart urealistisk.

Men noe gjennombrudd i kunnskap, slik som forskningen har gitt om de individualpreventive resultater av forskjellige reaksjoner, har man ikke fått. Forskningen har gitt brokker av kunnskap som kan brukes til kontroll og supplering av de commonsense pregede resonnementer som man fremdeles vil være henvist til. Det er meget langt igjen $\mathrm{f} \phi \mathrm{r}$ forskningen kan gi kvantifiserbare resultater om hvilken virkning på kriminaliteten man kan vente som følge av den ene eller annen påtenkte endring i systemet, om man nå noen gang kommer derhen. Enkelte forskere har operert med utsagn av denne type. Dette gjelder særlig innenfor den statistiske komparative forskning (se således foran $\mathrm{i}$ avsnitt IV og V om Ehrlich's arbeider). Nettopp denne type av forskning stiller jeg meg personlig mest tvilende overfor. Inntil man har oppnådd en rimelig grad av enighet blant forskerne om metoder og resultater, ville det iallfall være forhastet å bygge kriminalpolitiske avgjørelser på slike beregninger.

Man kan reise spфrsmålet om hvor langt problemet om almenprevensjonen i det hele er tilgjengelig for forskning (,,researchable“). Særlig de langsiktige moralske virkninger av straffelov og rettshåndhevelse er vanskelige å kartlegge statistisk. Det er 
kanskje lite fruktbart i dag å spekulere over hvor langt man i det hele kan komme. Forskningen på dette felt er ennå i sin begynnerfase og det er beskjedne ressurser som er satt inn. Om 10 eller 20 år vil vi vite mer, også om hvor grensene går for muligheten for å komme frem til eksakt kunnskap.

Det sterkeste grunnlag for troen på almenprevensjonen er fremdeles den vel kjente erfaring at frykten for ubehagelige konsekvenser er en sterkt motiverende faktor i de fleste av livets forhold, og sterkere jo alvorligere de fryktede konsekvenser er. Det er en nesten fantastisk forestilling at denne velkjente mekanisme skulle være uten betydning når det er spørsmål om å begå eller ikke begå straffbare handlinger. En slik forestilling må forutsette at lovovertredere er en særskilt type mennesker som ikke lar seg påvirke av motiver på vanlig måte, eller at de befinner seg i en situasjon som utelukker normal motivasjon. Slike tilfelle forekommer naturligvis; man kan nevne psykopatologiske lovovertredere, forbrytelser begått under ekstreme følelsesmessige konfliktsituasjoner, eller av narkomane drevet av et overveldende behov for stoff. Men moderne forskning om den uregistrerte kriminalitet har vist at lovovertredelser er et meget mer utbredt fenomen enn man tidligere har regnet med. Det store flertall av lovovertredere, for ikke å tale om de potensielle lovovertredere, er nokså normale mennesker. Det er liten grunn til å gå ut fra at de er upåvirkelige av utsikten til negative konsekvenser, selv om det kan være store variasjoner $i$ påvirkeligheten. Jeg tror svært mange av egen erfaring kan vitne om at risikoen for oppdagelse og negative sanksjoner spiller en rolle ved lovovertredelser som skattesnyteri, smugling, promillekjøring og trafikkovertredelser. Det ligger selvsagt en fare i å generalisere ut fra seg selv. Kjennskap til andre grupper og deres innstillinger er viktig. Gjelder det moderne $\varnothing$ konomisk kriminalitet, er det viktig å ha kjennskap til innstillinger og praksis i forretningslivet. Gjelder det ungdommens vinningskriminalitet, er det på tilsvarende måte viktig med kjennskap til ungdomsmilj $\phi$ og ungdomsgjenger osv.

Det har etter min oppfatning vært en tendens hos kriminologer til å undervurdere betydningen av common sense resonnement om almenprevensjonen på grunnlag av vanlige psykologiske kjensgjerninger og dagliglivets erfaringer. Ikke noe forstandig menneske utenfor de profesjonelle kriminologers leir ville tvile på at størrelsen av en parkeringsbot og effektiviteten av håndhevelsen har betydning for antallet overtredelser, også f $\phi \mathbf{r}$ Chambliss intervjuet sine universitetskolleger og således brakte ,,empirisk“ eller „vitenskapelig“" bevis for sammenhengen. ${ }^{6}$ ) "Men

76) Se foran ved note 48 . 
forestillingen om at „straff ikke avskrekker fra lovovertredelser“ har vært så inngrodd blant kriminologer at det var n $\phi$ dvendig med en statistisk påvisning også av det selvinnlysende, og Chambliss' artikkel er blitt en av de mest siterte i litteraturen.

På den annen side har det vart en tendens til å overvurdere betydningen av de statistiske unders $\emptyset$ kelser som er foretatt, og til å generalisere ukritisk fra dem. Det klassiske eksempel er de tidligere unders $\phi$ kelser om betydningen av d $\phi$ dsstraff for drap og de generelle slutninger som ble trukket av dem. ${ }^{77}$ ) Man kan begå samme feil i tolkingen av den foreliggende forskning, hvis man ikke omhyggelig klargjør de begrensninger som er innebygget $\mathrm{i}$ de forskjellige metoder. Gibbs, som mer detaljert enn noen annen har drøftet de metodiske problemer ved forskningen, konkluderer i sin bok endog med at alt samfunnsvitenskapen kan gjøre i dag, er å understreke vanskelighetene ved å vurdere bevismaterialet for og imot antagelsene om almenprevensjonen (,the deterrence doctrine“).$^{78}$ )

\section{Almenprevensjon og kriminalpolitikk.}

Forskning alene gir ikke svar på hvilken politikk som b $\phi \mathbf{r}$ f $\varnothing$ res. Kriminalpolitikk som annen politikk forutsetter verdipremisser, som kan være bevisste eller ubevisste og mer eller mindre eksplisitt formulert. ̊̊ utforme en politikk vil si å anvende et sett verdipremisser på et sett mer eller mindre vel begrunnede antagelser om virkningene av forskjellige mulige løsninger.

De nedslående forskningsresultater om de individualpreventive virkninger av forskjellige reaksjoner overfor lovovertredere har f $\phi$ rt til at det faktiske underlag for de kriminalpolitiske beslutninger er blitt et annet. Jeg mener nok for min del at både behandling og uskadeliggjørelse har en legitim plass i det strafferettslige systemet, men dets primære oppgave må være almenprevensjonen, bygget på en kombinasjon av avskrekking og moralpåvirkning - selvsagt innenfor de grenser som kravet til rettferdighet og humanitet setter. Det grunnleggende trekk i den strafferettslige kontrollteknikk er at loven stiller opp en norm og truer overtredelse med straff for å skape et motiv for å overholde normen. Reaksjonen i det konkrete tilfelle har først og fremst til oppgave å sette alvor bak truselen. ${ }^{79}$ )

Det er ofte sagt at å bygge på almenprevensjonen, leder til overdreven strenghet. Det er en uholdbar generalisering. Lov-

77) Se foran i avsnitt IV.

78) Jack P. Gibbs, Crime, Punishment, and Deterrence (1975) s. 238.

79) Jfr. Andenæs, Fremtidsperspektiver på strafferetten, Lov og Rett 1973 s. $339-359$, se især s. $345-346$ (også i Straff og lovlydighet, 2. utg. s. $170-171)$. 
lydighet er ikke et mål som er verd en hvilken som helst pris. Det man oppnår, må veies mot det som det koster - i dette tilfelle det ubehag eller den lidelse som påf $\varnothing$ res lovbryterne og deres familier og de фkonomiske kostnader for samfunnet. Det er nok så at almenpreventive hensyn ofte har vært anført som begrunnelse for krav om strenge straffer. Et avskrekkingssystem som ikke er holdt i tømme av krav om rettferdighet og humanitet kan bli et terrorvelde - det er nok å nevne navn som Hitler og Stalin. Dette kan gi noe av forklaringen på den utbredte motvilje mot å akseptere almenprevensjonen som en realitet. Men noen n $\phi \mathrm{d}-$ vendig sammenheng mellom et almenpreventivt perspektiv på straffesystemet og krav om at straffene skal være strenge, er det ikke. Den finske Straffrättskommittén har således stilt seg det mål å redusere den lidelse som er forbundet med fullbyrdelse av straff samtidig med at det blir lagt st $\varnothing$ rre vekt på den almenpreventive virkning av straffesystemet. ${ }^{80}$ )

En annen innvending som har vært anf $\phi$ rt mot det almenpreventive perspektiv på strafferetten, er at det virker konserverende og tar sikte på å opprettholde status quo i samfunnet.81) Dette er åpenbart uholdbart. En strafferett basert på almenprevensjon kan like gjerne brukes som et middel til å gjennomf $\varnothing \mathrm{re}$ samfunnsmessige endringer som til å opprettholde den bestående tilstand.

Siden vårt kjennskap til den betydning straffenivået har for kriminaliteten er så begrenset, kan det være naturlig å legge vekt på hva som ut fra nåtidens verdiforestillinger fremtrer som en rimelig straff; rimelig både $\mathrm{i}$ forhold til lovovertredelsens grovhet og i forhold til andre typer straffbare handlinger. At oppfatningene om det rimelige kan variere, er selvsagt. Utviklingen har gått i retning av mildere straffer, og især mindre bruk av frihetsstraff. Internasjonalt sett er straffene i de nordiske land milde, men i Holland er de enda betydelig mildere, og tendensen der har iallfall inntil den siste tid gătt stadig lenger $i$ denne retning. Det vil være interessant å se hvor langt man kan gå i mildhet uten at det har alvorlige konsekvenser for kriminaliteten.

Unders $\varnothing$ kelsene omkring publikums kunnskap om strafferettssystemet har festet oppmerksomheten på det forhold at det er de enkeltes oppfatninger om straffens strenghet og visshet som er avgjørende for den almenpreventive virkning, ikke de objektive forhold. Vil man oppnå maksimal effektivitet, gjelder det derfor å gi publikum inntrykk av at risikoen er stor og straffen streng. Dette er et poeng som heller ikke tidligere har gått praktikere

${ }^{80}$ ) Se Patrik Törnudd i konferanserapporten General Deterrence.

81) Se Hanns V. Hofer og Henrik Tham, Beware of General Prevention! I konferanserapporten General Deterrence s. 257. 
forbi. Det norske trafikkpoliti (utrykningspolitiet) har i en årrekke med god hjelp av pressen, men uten å gi direkte uriktige opplysninger, vært i stand til å skape et sterkere inntrykk av risikoen for trafikkontroll enn jeg har inntrykk av at det objektivt sett er grunnlag for.

Muligheten er imidlertid begrenset. Å f $\varnothing$ re folk bak lyset ved å gi uriktige opplysninger, er forkastelig av etiske grunner, og kan også gi bakslag hvis det blir avslфrt. Jeg synes nok Mäkelä går lenger enn jeg kan f $\varnothing$ lge ham når han uttalers2):

„Med alla medel borde man sträva till att befolkningen tror att straffnivån är mycket högre än vad den faktiskt är, Därför är det till exempel bra om man utdömer långa frihetsstraff som publiceras i pressen, men sedan kan ju brottslingen släppas ut när han suttit en femtedel av det utmätta straffet. På motsvarende sätt borde reportrar och exkursionsgrupper bara få se de gammalmodigaste och gruvligaste avdelningarna på fängelset. Under tiden skulle fångarne kunna sitta i mysiga sällskapsrum och titta på TV“.

I et demokratisk samfunn med en fri presse er det vanskelig å regulere informasjonsstr $\phi$ mmen med sikte på at den skal tjene rettsvesenets formål. Den britiske promillelovgivning gir eksempel på at en høy oppfatning av risikoen ble skapt gjennom en omfattende publisitet, men virkningen tapte seg etterhvert som publikum forstod at risikoen ikke var så stor som man hadde tenkt seg.

Det kan likevel være grunn til å ta spørsmålet om formen for kommunikasjon mellom rettsvesen og borgere alvorlig. Ser man på lovgivning og rettspleie som et stort maskineri med den oppgave å dirigere borgernes adferd, er det ikke nok å sørge for at lover blir vedtatt og overtredelser påtalt; det bør legges stor vekt på å få rettsstoffet presentert så det får et maksimum av psykologisk gjennomslagskraft. Etter utdannelse og yrkestradisjon er det naturlig at strafferettspleiens embetsmenn ser det som sin oppgave å få lovovertredelser oppsport og påd $\varnothing \mathrm{mt}$, ikke å drive public relation-virksomhet. Den publisitet som følger med, er de vel ofte tilb $\phi y e l i g e$ til å se på som et uunngåelig onde. Det kan her være behov for en viss nytenkning. I dag er det tilfeldigheter som avgj $\phi \mathbf{r}$ hvilke saker som blir trukket frem og kommentert $\mathrm{i}$ pressen, og det er ikke sikkert at det er de som man helst kunne $\phi$ nske ut fra almenpreventive hensyn. For noen år siden begynte den norske h $\phi$ yesterett å gi ubetingede fengselsdommer for særlig graverende hastighetsoverskridelser, selv om de ikke hadde resultert i noe ulykke. Det skjedde av almenpreventive

82) Klaus Mäkelä, Om straffens verkningar. Oikeustiede VI (1975) s. 237 (se s. $257-258$ ). 
grunner. Men denne praksis var fullstendig ukjent for den store masse av bilkjørere inntil en journalist for noen tid siden slo forholdet opp i pressen. Burde ikke rettspleiens folk selv s $\varnothing$ rge for at rettsavgjørelser som kan ha en positiv betydning for almenprevensjonen får den nødvendige publisitet?

\section{Almenprevensjon og kriminologisk teori.}

For en strafferettsjurist har det alltid virket litt merkelig at kriminologiske læreb $\phi k$ er og andre fremstillinger har of ret så liten oppmerksomhet på de almenpreventive virkninger av straffeloven og rettsmaskineriet. Tittle og Rowe har nylig pekt på at en tilfredsstillende forklaring av sosial adferd må ta i betraktning både drivkrefter (pushes) og avholdende krefter (restraints), men at mesteparten av det arbeid som er utført i de siste f $\phi r t i$ år har lagt uforholdsmessig vekt på drivkreftene eller motivasjonen, altså bare halvparten av formelen. ${ }^{s 3}$ ) De antyder til og med at den dominerende faktor i menneskelig adferd kan være frykt for sanksjon, og at mange adferdsteorier kunne bli integrert $i$ en slik avskrekkingsramme.

Jeg tror dette er å stille for store forventninger til avskrekkingsperspektivet som forklaringsmoment. Men utvilsomt er frykt for negative konsekvenser en viktig forklaringsgrunn til menneskelig adferd. Våre omgivelser (familie, venner, kolleger, overordnede) vil reagere med misbilligelse og kanskje avvisning og isolasjon hvis vi ikke lever opp til deres forventninger og krav. Naturen selv straffer oss med kulde og t $\varnothing$ rst og kanskje d $\varnothing$ den hvis vi ikke tar våre forholdsregler $\mathrm{f} \phi \mathbf{r}$ vi f. eks. legger ut på en tur på høyfjellet vinterstid. Loven truer oss med rettslige sanksjoner, fra den lille parkeringsboten til alvorlige straffer som innebærer vanære og lidelse, hvis vi trosser dens forbud og påbud. Dette betyr ikke at vi går rundt i en evig kamp mellom lyst og frykt. Det ville gjøre livet uutholdelig. Vi tilpasser oss, vi tar i betraktning de negative konsekvenser, vi legger oss til med innstillinger, vaner og livsstil som holder oss så noenlunde innenfor de rette grenser uten noen f $\varnothing$ lelse av konflikt eller tvang. Loven med sin straffetrusel er en av kreftene i denne prosessen.

Dette perspektivet gir også et inntak til forklaring av lovbrytergruppens sammensetning. I et strafferettssystem som arbeider med en rimelig grad av effektivitet - og med det mener jeg et system hvor oppdagelsesrisikoen og straffens størrelse gir et rasjonelt motiv for å avstå fra lovbrudd — der vil den store majoritet holde seg på den rette side av loven; deres mulige lovbrudd

83) Charles R. Tittle og Alan R. Rowe, Certainty of Arrest and Crime Rates: A Further Test of the Deterrence Hypothesis. Social Forces Vol. 52 (1974) s. 455. 
vil være små og tilfeldige. Den sosialt vellykkede og psykisk avbalanserte vil ha meget å tape ved rettergang og straff, og han har evnen til å innrette seg rasjonelt på lang sikt. De som ikke lar seg motivere av straffetruselen, er de sosialt mindre vellykkede eller personlig ubalanserte. For å sette det på spissen: En lovbrytergruppe med en sosialt og personlighetsmessig representativ sammensetning kan en bare vente å finne under forhold hvor straffetruselen er så lite effektiv at den ikke blir tatt alvorlig. Rettshåndhevelsens effektivitet blir dermed en vesentlig forklaringsgrunn for lovbrytergruppens egenskaper. Jo strengere og mer effektivt en bestemt handlingstype er kriminalisert, jo mer avvikende vil lovbrytergruppen under ellers like forhold være.

Promillekjøring gir et godt eksempel på denne utsilende virkning av straffesystemet. Forskning fra de senere år viser at domfelte promillekjørere har adskillig til felles med et vanlig fengselsklientel. Det er yrkesmessig en klar overrepresentasjon av personer med svak utdanning og lav sosial og $\phi$ konomisk status. En stor del er tidligere straffet, dels for promillekj $\phi$ ring, dels for tyveri og andre forbrytelser. Svart mange har store alkoholproblemer, særlig av dem som har kjørt med høy promille. Naturligvis ville den gruppe som kjører motorvogn under innflytelse av alkohol, ikke ha vært noe tverrsnitt av samtlige førere selv om det ikke hadde eksistert noen straffebestemmelse på området. Men det kan ikke være noen rimelig tvil om at eksistensen og håndhevelsen av de strenge straffebestemmelser, og sosialgruppers og individers forskjellige reaksjoner på dem, gir en vesentlig del av forklaringen på den nåværende sammensetning av gruppen.

For promillekj $\phi$ ringens vedkommende er denne utsilingsmekanisme lett å iaktta, selv om det ikke er enkelt å finne noe statistisk mål for den. For andre typer lovovertredelser, f. eks. vanlige vinnings- og voldsforbrytelser, er denne sammenheng kanskje overskygget av andre og lettere konstaterbare årsaksmekanismer. Men i prinsippet står vi her overfor en lovmessighet som er innebygget i selve straffesystemets virkemåte, og som har fått altfor liten oppmerksomhet i kriminologisk teori. 